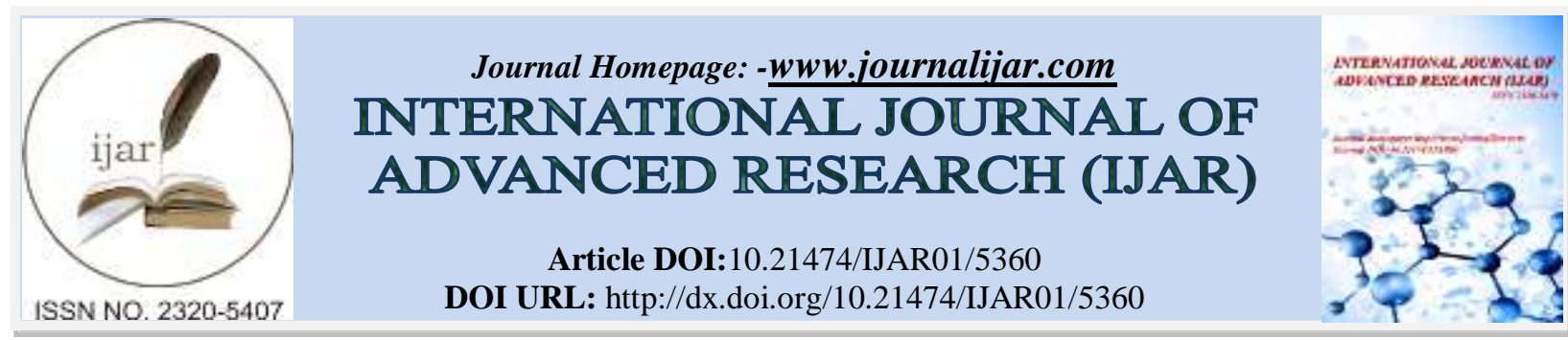

RESEARCH ARTICLE

\title{
A STUDY ABOUT GROWTH OF BSNL BROADBAND SERVICES IN RAJASTHAN.
}

\section{Ramdeo Arya ${ }^{1}$ and Prof. J K Tandon ${ }^{2}$.}

1. Research Scholar, School of Business and Management, Jaipur National University, Jaipur 302025, Rajasthan, India.

2. Research Advisor, School of Business and Management, Jaipur National University, Jaipur 302025, Rajasthan, India.

\section{Manuscript Info}

Manuscript History

Received: 08 July 2017

Final Accepted: 10 August 2017

Published: September 2017

Key words:-

ADSL2 Broadband, FTTH, CAGR, ABF.

\section{Abstract}

Broadband not only plays a critical role in the workings of the economy, it connects consumers, businesses, governments and facilitates social interaction. Broadband policies have now become a vital part of broader ICT policy strategies and have now receiving the same attention as other key economic policies. With the advancement of technological development in every field data business has also grown like anything. India also has grown from no-where to a giant in this business because of huge subscriber base and escalating demands. The emphasis was on acquiring more and more data subscribers by offering better speed and network quality. Telecom Operators have witnessed lot of challenges in terms of intense competition and managing growing customer expectations on one hand and difficulties in growing and maintaining the telecom infrastructure/network. This study detailed about the Induction, Customer Acquisitions, Adoption, competition, Challenges, Marketing strategies, Growth of ADSL2 broadband and FTTH services of M/s Bharat Sanchar Nigam Limited in Rajasthan and analyze the factors that led to the growth, its future prospects and challenges that were an impediment to its growth and finally some suggestions and recommendations to overcome those challenges. The tools used in the analysis were the Microsoft excel and compounded average growth rate for reaching conclusion on growth of broadband services of BSNL in Rajasthan. From study it was concluded that for ADSL2 (Asynchronous Digital lines) based Broadband and FTTH (Fiber to the home) of BSNL Rajasthan the CAGR (Compounded Average Growth Rate) of average connections, $\mathrm{ABF}$ (Amount Billed For) and Revenue recovered were 8.08\%, 12.19\% and $12.39 \%$ for whole Rajasthan respectively and Jhunjhunu SSA recorded highest CAGR of average connections, ABF (Amount Billed For) and Revenue recovered as $19.98 \%, 27.31 \%$ and $26.21 \%$ respectively.

Copy Right, IJAR, 2017,. All rights reserved.
Corresponding Author:- Ramdeo Arya.

Address:- Research Scholar, School of Business and Management, Jaipur National University, Jaipur 302025, Rajasthan, India. 


\section{Introduction:-}

The broadband services in BSNL Rajasthan were started in March-2005 on copper pairs. Initially there were many hurdles, challenges and bottlenecks right from policy making, procurement of equipment, customer acquisition and marketing strategies for the growth of broadband services. The procurement was made pan India and distributed to all the circles of BSNL including Rajasthan. Due to lack of PC penetration in urban and especially in rural area there were many difficulties in acquiring the broadband customers. BSNL Rajasthan had taken many steps for the growth of these services. Area wise Rajasthan the largest state in India and many districts with very low population had many more difficulties in acquiring the customers. This article analyze the factors that led to the growth, its future prospects and challenges that were an impediment to its growth and finally some suggestions and recommendations to overcome those challenges.

1.1 General: -The Telecom Sector witnessed substantial growth in the number of subscribers during the recent years. At the end of the financial year (2016-17), the subscriber base was 1194.58 million out of which 1170.18 million were wireless subscribers. During the year of 2016-17, wireless subscriber base recorded an increase of 136 million, while the overall Tele-density increased from 83.36 to 91.08 . The year also saw increase in rural Teledensity from 51.37 to 56.47 while the urban Tele-density also increased from 154.01 to 166.71 (Source: -DOT, Annual Report 2016-17 and TRAI Telecom subscription data as on 31.03.2017) ${ }^{13,14}$.

India is currently the second-largest telecommunication market in the world with Rajasthan alone having $7.5 \mathrm{Cr}$ mobile connection. To cater such a huge pool of Tele-users many private players are rubbing shoulders to have a niche in the highly competitive telecommunication sector. Major telecom service providers in Rajasthan are- Airtel, Aircel, BSNL, IDEA, MTS, RCL, RJIL, TTSL and Vodafone.

The entry of private service providers brought with it the inevitable need for independent regulator. The Telecom Regulatory Authority of India (TRAI) was, thus, established with effect from 20th February 1997 by an Act of Parliament, called the Telecom Regulatory Authority of India Act, 1997, to regulate telecom services, including fixation/revision of tariffs for telecom services which were earlier vested in the Central Government. ${ }^{13}$

1.2 Government of India's Telecom and Broadband Policies: -According to the World Bank, 10\% growth of broadband penetration rate will drive 1.4\% growth of GDP (Gross Domestic Product). Government of India launched it's an ambitious program "Digital India" on 1st June, 15. The success of this program depends totally upon ubiquity of broadband services in India. In the technological era of today, the "Broadband" has become the life line of internet users. It encompasses the technology and equipment for the digital delivery of voice, video and data services. In a short time broadband has become a driver for all types of industries whether manufacturers or service providers. Definitely within these industries, broadband as a market driver has reached ubiquity but not up to the last mile user. Broad band's importance is certainly on the rise. It plays a significantly important role in the successful running of business, transparent and smooth functioning of Government but also day to day life of even a common man is governed by it. The global growth of electronic commerce shows that people are becoming increasingly dependent on the Internet for communications and all type of services ${ }^{14}$.

1.2a-NTP-1994-National Telecom Policy (NTP), 1994 recognized that the required resources for achieving the targets set under the policy would not be available from government sources and concluded that investment and involvement from private sector were required to bridge the resource gap and opening up of the telecom sector in basic services as well as value added services. It allowed participation of private companies in the telecom field except national long distance (NLD) and international long distance (ILD) services ${ }^{14}$.

1.2b-Telecom Regulatory Authority of India (TRAI)-In the context of privatization of telecommunication services following New Economic Policy (NEP), 1991 and NTP 1994, a multi-operator scenario emerged both in the basic as well as cellular services in which private operators were competing with government or government-owned entities. The government decided to set up an independent telecom regulatory authority. An ordinance was issued on January 25, 1997, establishing the Telecom Regulatory Authority of India (TRAI) as an independent regulatory agency for the telecom sector ${ }^{13}$.

1.2c-NTP-1999- Main features of National Telecom Policy 1999 were $^{14}$, Strengthening of the Regulator, Opening of NLD and ILD services to private sectors, License to private telecom operators on a revenue sharing basis, plus a one-time entry fee, Resolution of problems of existing operators envisaged, Direct interconnectivity and sharing of 
network with other telecom operators within the service area.NTP 1999 was amended in November 2003 which permitted a licensee to make available wire-line and wireless services using any technology in a pre-determined license area after conversion of the license to a Universal Access Service License (UASL) ${ }^{14}$.

1.2d-Licensing Framework- On liberalization of telecom sector the licenses were issued for (i) Cellular Mobile Telephone Service- in Territorial Telecom Circles maximum of two licenses were granted for CMTS in each service area initially and letter on more licenses to private service providers were given. (ii) MTNL and BSNL were issued licenses for provision of CMTS as third operator in various parts of the country. (iii) Unified Access ServiceUnified Access Service licensee were provided for wire-line as well as wireless services in a service area. Basic and cellular services licensees were permitted to migrate to UASL regime. (iv) National Long Distance Telephony- The government accordingly decided to open NLD service without any restriction on the number of operators to the private sector to carry inter-circle traffic in the country. (v) International Long Distance Telephony- The government opened the ILD services, which were basically a network carriage service, providing international connectivity to networks operated by foreign carriers. (vi) Licensing of Internet Services- the government opened up the sector to private operators with a view to increase Internet penetration across the country. (vii) 3G and BWA Spectrum Auctions- DoT issued 'Guidelines for Auction of Spectrum for $3 \mathrm{G}(2.1 \mathrm{Ghz}$ band) and BWA (2.3Ghz band)Services' in August 2008 through e-auction ${ }^{14}$.

1.2e-NTP-2012-This policy also recognizes the predominant role of the private sector in telecom field to strike a balance between the interests of users/ consumers, service providers and government revenue ${ }^{14}$.

- This policy has the vision Broadband on Demand and envisages leveraging telecom infrastructure to enable all citizens and businesses, both in rural and urban areas, to participate in the Internet and web economy thereby ensuring equitable and inclusive development across the nation. Further this policy-has vision to provide secure, reliable, affordable and high quality converged telecommunication services anytime, anywhere for an accelerated inclusive socio-economic development.

- This policy's few areas of mission were to develop a robust and secure state-of-the-art telecommunication network providing seamless coverage with special focus on rural and remote areas for bridging the digital divide and thereby facilitate socio-economic development and to create an inclusive knowledge society through proliferation of affordable and high quality broadband services across the nation.

- This policy has few of objectives which were (i) Provide affordable and reliable broadband-on-demand by the year 2015 and to achieve 175 million broadband connections by the year 2017 and 600 million by the year 2020 at minimum 2 Mbps download speed and making available higher speeds of at least $100 \mathrm{Mbps}$ on demand.(ii) Enable citizens to participate in and contribute to e-governance in key sectors like health, education, skill development, employment, governance, banking etc. to ensure equitable and inclusive growth.(iii) Provide high speed and high quality broadband access to all village panchayats through a combination of technologies by the year 2014 and progressively to all villages and habitations by 2020.(iv)Protect consumer interest by promoting informed consent, transparency and accountability in quality of service, tariff, usage etc. Strengthen the grievance redressal mechanisms to provide timely and effective resolution.

- This policy has few of strategies which were(i)Broadband ,rural, telephony and universal service obligation fund(USOF) -for developing an eco-system for broadband in close coordination with all stakeholders, including Ministries/ Government Departments/ Agencies to ensure availability of media for last mile access, aggregation layer, core network of adequate capacity, affordable equipment including user devices, terminals and Customer Premise Equipment and an environment for development of relevant applications. Formulate policies to promote competition by encouraging service providers, whether large or small, to provide value added services under equitable and non-discriminatory conditions.(ii) To recognise telecom, including broadband connectivity as a basic necessity like education and health and work towards 'Right to Broadband'(iii) To lay special emphasis on providing reliable and affordable broadband access to rural and remote areas by appropriate combination of optical fibre, wireless, VSAT and other technologies . Optical fibre network will be initially laid up to the village panchayat level by funding from the Universal Service Obligation Fund (USOF). Extension of optical fibre connectivity from village panchayats to be taken up progressively to all villages and habitations. Access to this Optical Fibre Network will be open, non-discriminatory and technology neutral.(iv) To revise the existing broadband download speed of $256 \mathrm{Kbps}$ to $512 \mathrm{Kbps}$ and subsequently to $2 \mathrm{Mbps}$ by 2015 and higher speeds of at least 100 Mbps thereafter.(v)To encourage Fibre To The Home (FTTH) with enabling guidelines and policies, favouring fast transformation of cities and towns into Always Connected society.(vi)To incorporate enabling provisions in the current regulatory framework so that existing infrastructure including cable TV networks are optimally utilised for extending high quality broadband services in rural areas also.(vii) To establish appropriate institutional framework to 
coordinate with different government departments/agencies for laying and upkeep of telecom cables including Optical Fibre Cables for rapid expansion of broadband in the country. (viii)To leverage the mobile device and SIM Card with enhanced features for enabling secure transactional services including online authentication of identity and financial services.(ix)To promote synergies between roll-out of broadband and various Government programs viz e- governance, e-panchayat, MNREGA, NKN, AADHAR, AAKASH tablet etc.(x)To stimulate the demand of broadband applications and services, work closely with Department of IT in the promotion of local content creation in regional languages which would enhance the investment in AllInternet Protocol (IP) networks including NGN ${ }^{14}$.

1.2f: Bandwidth requirement of many applications-(i) for Application like Internet surfing - Minimum Band width

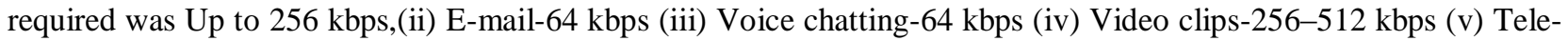
education-256-512 $\mathrm{kbps}$ (vi) Tele-Medicine-256 kbps to $4 \mathrm{Mbps}$ (vii) Video streaming per channel-2 Mbps (approx.)(viii) Video gaming-256-512 kbps (high precision games may require higher bandwidth)(ix) High Definition Video per channel-4-8 Mbps (x) Online gaming/video on demand/video streaming/IPTV-3-4 Mbps.

1.2g: Internet and Broadband Services: -As per guidelines for grant of Unified License dated August 19, 2013, the internet services have been included in the Unified License. As on March 31, 2017, there were 239 authorized Licensees for Internet Services which include 56 Category "A" Licensees, 106 Category "B" Licensees and 77 Category "C" Licensees .Further more on December 31, 2016, 625 Unified Licenses have been issued with ISP authorization. This includes 38 Category 'A' ISP authorizations, 269 Category 'B' ISP authorizations and 318 Category ' $C$ ' ISP authorizations. As on March 31, 2017, there were 276.52 million Broadband subscribers. QoS of Broadband Internet Services depends on, Network availability, Ratio of Local Bandwidth to Number of Users, Ratio of External Bandwidth to Number of Users, Network Latency in Local Route, Network Latency in External Route, Bandwidth Utilization in Local Route, Bandwidth Utilization in External Route ,Network Coverage ${ }^{13,14}$.

1.2h: Regulations- The regulation for QoS of broadband services was enacted in 2006 followed by many amendments. The salient features of Telecom Consumers Protection Data Regulation are as under (i) Information to consumers relating to usage of data through SMS or USSD-(ii) Information to mobile data users regarding data used, after every $10 \mathrm{MB}$ of data usage. (iii) Information to users of various special data packs (STV/ Combo/ add-on-pack), whenever the limit of data usage reaches $50 \%, 90 \%$ and $100 \%$ of data. (iv) Activation or Deactivation of data services:- with the explicit consent of the subscriber through a toll free short code $1925^{13}$.

1.2i-Broadband Policy 2004:- (By Government of India Ministry of Communications and Information Technology):

- It was recognized that the level of Internet and Broadband access in the country was low as compared to many Asian countries. Penetration of Broadband, Internet and Personal Computer (PC) in the country was $0.02 \%$, $0.4 \%$ and $0.8 \%$ respectively at the end of December, 2003. At that time, high speed Internet access was available at various speeds from 64 kilobits per second (kbps) onwards and later-on an always -on high speed Internet access at $128 \mathrm{kbps}$ was considered as 'Broadband" "There were no uniform standards for Broadband connectivity and various countries follow various standards. Government envisions an accelerated growth in Internet penetration and PC as the success of Broadband would largely be dependent on their spread. Recognizing the potential of ubiquitous Broadband service in growth of GDP and enhancement in quality of life through societal applications including tele-education, tele-medicine, e-governance, entertainment as well as employment generation by way of high speed access to information and web-based communication, Government finalised a policy in 2004 called broadband policy 2004 to accelerate the growth of Broadband services. Year 2007 was declared as Broadband Year by the Government of India ${ }^{14 .}$

- Broadband connectivity: Broadband connectivity was defined as “An 'always-on' data connection that was able to support interactive services including Internet access and has the capability of the minimum download speed of 256 kilobits per second (kbps) to an individual subscriber from the Point Of Presence (POP) of the service provider intending to provide Broadband service where multiple such individual Broadband connections were aggregated and the subscriber was able to access these interactive services including the Internet through this POP. The interactive services will exclude any services for which a separate license was specifically required, for example, real-time voice transmission, except to the extent that it was permitted under ISP license with Internet Telephony."

- The estimated growth for Internet subscribers in the country envisaged through various technologies for the year ending 2005 was 6 million, for 2007 was 18 million and for 2012 was 40 million. The estimated growth for 
Broadband subscribers in the country envisaged through various technologies for the year ending 2005 was 3 million, for 2007 was 9 million and for 2012 was 20 million.

- Technology Options for Broadband Services-The Broadband Policy Framework visualizes creation of infrastructure through various access technologies which can contribute to growth and can mutually coexist. These access technologies were Optical Fibre Technologies, Digital Subscriber Lines (DSL) on copper loop, Cable TV Network, Satellite Media, Terrestrial Wireless ,Future Technologies

- Other Issues--Bandwidth availability including international bandwidth is a major driver for broadband services. In a competitive environment, service providers are expected to take appropriate steps for making required bandwidth available in a time bound manner within their license framework. Cost of bandwidth constitutes a major cost component for Broadband services. Government and TRAI would address this issue on priority. Governments have recently decided to reduce the license fee for Infrastructure Provider category-II, who provides end to end bandwidth, to 6\% of Adjusted Gross Revenue (AGR). Further, the amount of bank guarantee for such service provider has also been reduced to Rs. $5 \mathrm{Cr}$ from Rs. $100 \mathrm{Cr}$.

- National Internet Exchange of India (NIXI) was set up by DIT, Government of India to ensure that Internet traffic, originating and destined for India, should be routed within India. It was expected that NIXI will take appropriate steps for increasing the utilization of such facilities.

- Role of other Agencies--PCs, content and applications are important constituents for overall growth of Internet and Broadband services. Broadband services will accelerate decentralized governance at Panchayat level.

- The role of other facilitators such as electricity authorities, Departments of ITs of various State Governments, Departments of Local Self Governments, Panchayats, Department of Health and Family Welfare, Department of Education was very important to carry the advantage of Broadband services to the users particularly in rural areas.

- Fiscal Issues--The Department of Telecommunications assigned a very high priority to indigenous manufacture of Broadband related equipment's. It was endeavoring to work closely with the concerned Ministries and Manufacturers' Associations so that the equipment's were available at an affordable price. The department was conscious of the fact that Broadband services can reach the urban and rural consumers only if services are offered at affordable and easy terms. Department of Telecommunications worked out a package in consultation with Ministry of Finance and related Departments as well as concerned service providers to achieve this. "

- Government need to push broadband deeper into the residential and small-business markets during the next two years, creating a true mass market for high-speed Internet access and opening new service possibilities and revenue opportunities ${ }^{14}$.

\section{2j- Deployment of Broadband in BSNL (All India level):}

- During 2003-04 it was seen that there was no growth in Wire line DELs and hence value addition was required. In addition the most precious asset of BSNL was the copper and utilization of existing cupper was required and there was an unbundling threat of copper pair for the purpose of other service providers.

- BSNL was to exploit the existing assets of huge optic fibre infrastructure spread to more than 400,000 kms reaching nook \& corner of the country and the extensive fibre overlay intra-city network. Also the huge copper based access network of 35 million customers, out of which around 50\% was new, only 4-5 years old \& was capable for broadband having typical copper loop is $2 \mathrm{kms}$ only.60000 HDSL existing customer and ultra-high IP MPLS core network of 10-city Gigabit POPs which was being expanded to 71 cities as part of NIB-II

- $\quad$ BSNL started the process by conceptualizing Project NIB-II to achieve overall objectives of BB policy 2004 with Poject1 and Project 2.1- for Core network, Project2.2- for Access network, Project3- billing and authentication. Broadband deployment was catered through Project 2.2 of NIB-II using ADSL technology. Tender done through two stage process. NIT floated by Karnataka Circle on 22/01/2004.First Year PO placed on 03/08/2004 and second year PO placed on 03/11/2004.50\% add on order through the same tender also processed. Service on a countrywide basis spanning 198 cities. Cities classified as A1, A2, A3, A4, B1, B2 and Other cities. Network supports ADSL, ADSL2 and ADSL 2plus and capacity of around eight Lacks by April 2005 and $20 \%$ of the CPEs was planned in the main tender. To take care of the balance requirement, a new tender of four lacks CPE has been floated by Karnataka Circle. Network commissioned on 14/01/2005

- Objective in Setting of B/B Network was high speed internet access for connecting broadband customers to MPLS VPN network, for connecting dial VPN customers to MPLS VPN network, to provide multicast video services, Bandwidth on demand, video-on-demand etc. through the BRAS ,billing by either time-based or volume-based billing and to provide support for both pre-paid and post-paid broadband services .

- The Features planned in BSNL Broadband were latest technology, Always ON connectivity, and simultaneous use with Telephone service, high Speed $256 \mathrm{kbps}$ to $2 \mathrm{Mbps}$ and other services to add progressively 
- Broadband Subscriber Target set- Accordingly targets set of one Million by December 2005, 3 Million by December 2006, and 6 Million by December 2007, 20 Million by December 2010.

\section{2k: Broadband Deployment in Rajasthan:}

$\rightarrow$ Project 1 of NIB-II-Under this project nodes at Jaipur, Jodhpur, Ajmer were installed .Jaipur was connected with Delhi and Mumbai over STM-16 links, Jodhpur was connected with Jaipur and Delhi over STM-1 links, Ajmer was connected with Jaipur and Delhi over STM-1 links. Infrastructure for MPLS VPN Service was used.

$\rightarrow$ Project 2.1 of NIB-II- Under this project for $1^{\text {st }}$ year total capacity (of $90 \mathrm{E} 1$ with customer to port ratio 15, of 40500 ports) was made available and for $2^{\text {nd }}$ year total capacity (of $145 \mathrm{E} 1$ with customer to port ratio 15 of 65250 ports) was made available.

$\rightarrow$ Project 2.2 of NIB-II- Under this project main P.O (488k) ports with 50\% add on P.O (244k) and Additional Expansion (300k) was ordered at all India level. In Rajasthan one BRAS , one Tier-1 switch, 15 Tier-2 switches at Jaipur ,Jodhpur, Ajmer, Udaipur, Sriganganagar, Bikaner, Kota ,Bhilwara and DSLAMs with total capacity of 20K and CPEs $4 \mathrm{~K}$ were ordered and installed.

$\rightarrow$ Project 2.2 Broadband Equipment 50\% Add on P.O.-Under this project new cities Alwar and Chittorgarh covered, additional Tier 2 Switches to Udaipur and Jaipur installed and DSLAMs at Bikaner, Kota, Ajmer, Udaipur were installed of capacity 750 ports

$\rightarrow$ Project 2.2 Broadband Equipment Additional Expansion. Under this project new cities: Bharatpur, Jhunjhunu, Pali, Sikar, Hanumangarh covered with expansion in existing cities and with port capacity of 7839 ,five Tier-2 switches and one Tier-1 switch installed.

$\rightarrow$ Overall Broadband equipment provisioning in Rajasthan: The broadband equipment was delivered in many projects/phases which included NIB-II (Project 2.1 for core equipment, Project 2.2 for DSLAMs, LAN switches, T1, T-2 switches, BNG, OCLAN's), Multi-play equipment (main, Ph-I, Ph-II, Ph-III), Rural (Main, Expansion).

Table 1:-Broadband equipment planning and provisioning in Rajasthan:

\begin{tabular}{|l|l|l|l|l|l|l|l|}
\hline Project & Vendor & $\begin{array}{l}\text { BRAS/ } \\
\text { BNG }\end{array}$ & $\begin{array}{l}\text { Tier-1 } \\
\text { Switch }\end{array}$ & $\begin{array}{l}\text { Tier-2 } \\
\text { Switch }\end{array}$ & $\begin{array}{l}\text { LAN } \\
\text { Switch }\end{array}$ & DSLAMs & $\begin{array}{l}\text { ADSL } \\
\text { Ports }\end{array}$ \\
\hline NIB-II Proj 2.2 & HTL / Huawei & 1 & 1 & 28 & - & 196 & 36776 \\
\hline Multi play & $\begin{array}{l}\text { UTStar \& } \\
\text { ZTE }\end{array}$ & 4 & 7 & 19 & 51 & $661+20$ & 128200 \\
\hline Rural & NSN & - & - & - & 95 & 1034 & 66176 \\
\hline MP Expn Ph-I & $\begin{array}{l}\text { UTStar\& } \\
\text { NSN }\end{array}$ & 5 & 3 & 8 & 90 & 202 & 81744 \\
\hline MP Expn Ph-II & ZTE & - & - & - & - & 21 DSLAMs 325 Cards & 26272 \\
\hline Rural Expn & ZTE & - & - & - & - & 454 & 29056 \\
\hline $\begin{array}{l}\text { MP Expn Ph- } \\
\text { III }\end{array}$ & ZTE & - & - & - & - & 200 cards & 12800 \\
\hline Total & & 10 & 11 & 55 & 236 & 2588 & 378624 \\
\hline
\end{tabular}

1.3 National Telecom Statistics: -

1.3aTelecom Subscriber data:

- India is currently the 2 nd largest Telecommunication market $\&$ has the 3 rd highest number of internet users in the world

- India's telephone subscriber base expanded at a CAGR of 19.22 per cent, reaching 1194.58 million during FY07-17.

- Tele-density (defined as the number of telephone connections for every hundred individuals) in India, increased from 14.6 in FY07 to 92.98 in FY17

- In March 2017, total telephone subscription stood at 1194.58 million, while Tele-density was at 92.98 percent

- During FY07-17, wireless subscriptions in the country increased at a CAGR of 21.64 per cent, with the number of subscribers reaching to 1170.18 million in FY17 
- In FY17, urban wireless Tele-density stood at 166.71 while rural wireless Tele-density stood at 56.47 and overall wireless Tele-density was 91.08

- India is the world's 2nd largest smart phone market $\&$ is expected to have almost 1 billion unique mobile subscribers by 2020

- The mobile segment's Tele-density surged more than 6 times from 14.6 per cent in FY07 to 91.08 per cent, in FY17

- $\quad$ GSM services continue to dominate the wireless market with a 95.73 per cent share (as of March 2017); while CDMA services accounted for the remaining 4.27 per cent share

- Indian telecom sector's revenue grew at a CAGR of 5.34 per cent to USD39.2 billion in FY17 as compared to USD19.6 billion in FY06

- Revenues from the telecom equipment were estimated at USD20 billion in FY16, which is further expected to touch USD30 billion in FY20.

- India's Broadband subscriber base expanded at a CAGR of 65.44 per cent, reaching 276.52 million during FY07-17.

Table 2:-Growth in total subscribers, wireless, Broadband and Tele-density total and wireless Tele-density

\begin{tabular}{|l|l|l|l|l|l|l|}
\hline $\begin{array}{l}\text { At the end } \\
\text { of March }\end{array}$ & $\begin{array}{l}\text { Total } \\
\text { Connections } \\
\text { in Millions }\end{array}$ & $\begin{array}{l}\text { Total Tele } \\
\text { Density (per 100 } \\
\text { population) }\end{array}$ & $\begin{array}{l}\text { Wireless } \\
\text { Connections } \\
\text { in Million) }\end{array}$ & $\begin{array}{l}\text { Wireless Tele } \\
\text { Density (per 100 } \\
\text { population) }\end{array}$ & $\begin{array}{l}\text { Telecom } \\
\text { Sector } \\
\text { Revenue } \\
\text { (USD Billion) }\end{array}$ & $\begin{array}{l}\text { Broadband } \\
\text { (in Million) } \\
\text { with } \\
\text { kbps }\end{array}$ \\
\hline FY 07 & 205.86 & 18.23 & 165.00 & 14.60 & 23.30 & 1.80 \\
\hline FY08 & 300.49 & 26.22 & 261.00 & 22.80 & 32.10 & 3.87 \\
\hline FY 09 & 429.72 & 36.98 & 392.00 & 33.70 & 33.20 & 6.22 \\
\hline FY 10 & 621.28 & 52.74 & 584.00 & 49.70 & 33.30 & 8.77 \\
\hline FY 11 & 846.33 & 70.89 & 812.00 & 68.00 & 37.70 & 11.89 \\
\hline FY 12 & 951.34 & 78.66 & 919.00 & 76.00 & 40.80 & 13.81 \\
\hline FY 13 & 898.02 & 73.32 & 868.00 & 70.90 & 39.10 & 15.05 \\
\hline FY 14 & 933.02 & 75.23 & 905.00 & 75.43 & 38.80 & 60.87 \\
\hline FY 15 & 996.00 & 79.36 & 970.00 & 77.27 & 41.70 & 99.20 \\
\hline FY 16 & 1058.86 & 83.36 & 1034.00 & 81.38 & 39.20 & 149.75 \\
\hline FY 17 & 1194.58 & 92.98 & 1170.00 & 91.08 & 39.20 & 276.52 \\
\hline CAGR in $\%$ & $19.22 \%$ & $17.70 \%$ & $21.64 \%$ & $20.09 \%$ & $5.34 \%$ & $65.44 \%$ \\
\hline
\end{tabular}

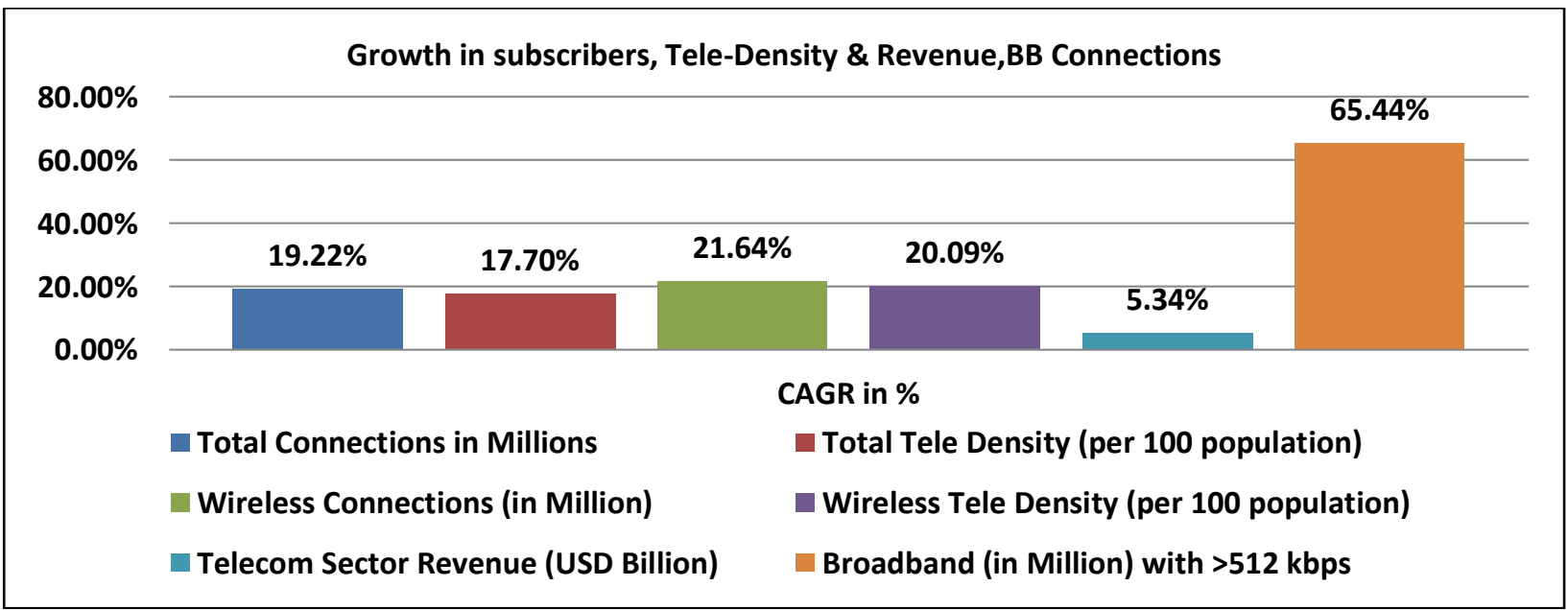

Source: Telecom Regulatory Authority of India

Fig 1: -Growth in subscribers, Tele-Density \& Revenue \& Broadband Connections

1.3b Average Speed (MBPS) with comparison to Major countries: - The average speed (in MBPS) of South Korea->23.6, Ireland ->17.6, Hong Kong ->16.7, Sweden ->15.8, Netherland ->15.3, Japan->15.2, Switzerland- 
$>14.9$,Norway->14.1 ,Latvia->13.8,Finland->13.7,USA->11.9,China->3.7, and Brazil->3.4.Compared to other major countries the average speed (MBPS) of India has lowest as 2.3 MBPS.

\section{Methodology:-}

2.1 Justification: -Consequent on, the declaration of NTP 1994, NTP 1999, formation of BSNL in Oct 2000, Broadband policy 2004 and NTP 2012, the broad band services were started in PAN India basis in the network of BSNL on wired lines. In Rajasthan LSA also it was started in March 2005.Initially it was started in limited cities and later on covered the whole Rajasthan. The important points considered for justification of taking up this study were:

- Wired lines services were mainly provided by BSNL in Rajasthan and Broadband services were provided on wired line on ADSL technology.

- $\quad$ BSNL was first entrant in providing broadband services on wired lines in Rajasthan LSA.

- The researcher was the circle coordinator for induction, adoption, customer acquisition, marketing strategies and growth of broadband services (on wired line) in Rajasthan license service area.

- New service provider's entry in $3 \mathrm{G}$ and $4 \mathrm{G}$ services in which data services were main target for acquisition of new consumers.

- Induction of FTTH broadband services in Rajasthan LSA on fiber optics by BSNL.

- There were many hurdle for proper adoption of broadband services in Rajasthan like, timely procurement of Broadband equipment, infrastructure preparation, less knowledge about PC's in general public, poor penetration and availability of Personal computers, less trained manpower to handle this new service, speed of broadband services in ADSL technology due to poor health of local loop on copper pairs in some areas, maintainability of broadband services and legacy of government department in working culture of the BSNL staff, availability of international bandwidth.

Hence it was felt by the researcher to have a study the growth of broadband services in BSNL Rajasthan and analyze the factors that led to the growth, its future prospects and challenges that were an impediment to its growth.

2.2 Objective

(i) To enumerate the details about induction, customer acquisition, adoption and growth of Broadband services of $\mathrm{M} / \mathrm{s}$ BSNL in Rajasthan License service area

(ii) To analyze the factors that led to the growth of BSNL BB services in Rajasthan LSA.

(iii) To enumerate the future prospects, Challenges in the growth of BSNL Broadband services in Rajasthan LSA.

(iv) To detail the recommendations and suggestions to overcome the challenges and bottlenecks.

\subsection{Period of Analysis}

The period of study was from April 2005 to March 2017.The researcher worked as GM (IT \& BD) in BSNL Rajasthan telecom circle from $6^{\text {th }}$ Oct 2003 to $18^{\text {th }}$ April2008. The help of BSNL Rajasthan circle at Jaipur was also taken for the extended period from $19^{\text {th }}$ April 2008 to 31.03. 2017. The ADSL based broadband services were launched in March 2005 in few cities of Rajasthan and later on it was covered in all districts and all telephone exchanges of Rajasthan by 2008. The FTTH services were inducted in BSNL Rajasthan network in 2009-10 on fibre. The separate BB revenue stream was started from 2009-10 as earlier the BB revenue was incorporated in landline revenue. Hence actual analysis was limited from 2009-10 to 2016-17.

\subsection{Data Collection}

The secondary set of data was collected from DOT's and TRAI's website as well as from operation wing, finance and development wing of BSNL Rajasthan Circle at Jaipur. The finance related data were collected from Senior GM(Finance) of BSNL Rajasthan circle and then data ,telecom statistics related with broadband, landline, GSM, CDMA, FTTH, internet was taken from operation, development wing of Rajasthan circle of BSNL. The researcher has also worked as GM (IT \& BD) as broadband circle coordinator in BSNL Rajasthan circle at Jaipur and was having knowledge about data related with procurement of equipment and step by step growth of broadband services of BSNL in Rajasthan LSA.

2.5 Tools used: In this study the secondary data was used and the compounded annual growth rate was taken for assessing the actual growth in capacity expansion, connection provisioning, revenue growth in ABF (amount billed for) and revenue realization

Following formulae was used for CAGR (Compounded Annual Growth Rate): 


\section{Data Analysis and tabulation and graphical representation of results:}

\subsection{Rajasthan Statistics: -}

3.1a-Status of different services in Rajasthan Circle: From the table no 3, 4, and 5 it was analyzed that

- There was a decline in wired line connections of BSNL Rajasthan by $65 \%$. This was due to the fact that there was a churn from land line connections to mobile connections. The compounded annual growth rate was $9.10 \%$.

- There was a $316 \%$ growth in wireless connections of BSNL Rajasthan. These include CDMA \& GSM connections. There was a sharp decline in the wireless connections in 2014-15 and 2015-016 (March ending). This was due to disconnections of CDMA customers and purging of inactive mobile connections. The CAGR of wireless connections in Rajasthan was observed as $13.85 \%$.

- In BSNL Rajasthan from the 2006 to 2017 there was a $24.60 \%$ compounded annual growth(CAGR) in ADSL broadband connections and number of ADSL broadband connections increased from 20045 to 225271.

- In BSNL Rajasthan from the 2006 to 2017 there was a $29.06 \%$ compounded annual growth(CAGR) in ADSL broadband capacity and capacity of ADSL broadband lines increased from 26524 to 438976.

- In BSNL Rajasthan from the 2006 to 2017 there was a $11.27 \%$ compounded annual growth(CAGR) in ADSL broadband revenue and ADSL broadband revenue increased from $108.8 \mathrm{Cr}$ to $229.72 \mathrm{Cr}$. Since commissioning of ADSL broadband services in BSNL Rajasthan in 2005 till 2009 the revenue of these services were counted in land line revenues and in 2010 the revenue of BB services was bifurcated. This was emerged as a new revenue stream for BSNL and acted as bread and butter for BSNL as land line was continuously getting churned in mobile services. To some extent BB services stopped the churning of land line connections.

- In 2009-10 the FTTH service started on optical fibre for providing broadband connections on fibre. In BSNL Rajasthan from the 2010 to 2017 there was a $107.97 \%$ compounded annual growth(CAGR) in FTTH connections and FTTH connections increased from 53 to 8917. This has helped BSNL to provide connections on optical fibre rather than land line local loop. This reduced the local loop loses and their-by increased the stability of broadband connection as well as increased the broadband speed.

- In BSNL Rajasthan from the 2010 to 2017 there was a $0.06 \%$ compounded annual growth(CAGR) in FTTH capacity and FTTH capacity was more or less remained same to 45248 as there was lot of efforts required by BSNL for providing FTTH connections and initial capacity was not utilized so far.

- In BSNL Rajasthan from the 2009 to 2017 there was a $58.07 \%$ compounded annual growth(CAGR) in FTTH revenue and this revenue increased from $1.69 \mathrm{Cr}$ to $16.68 \mathrm{Cr}$. Since commissioning of FTTH services in BSNL Rajasthan in 2009 till 2011 the revenue of these services were counted negligible as it did not pick up initially. In 2012 the revenue of FTTH services was bifurcated. This was emerged as a new revenue stream for BSNL. More marketing efforts required to popularize these services.

- Now two types of technology, one was ADSL BB and other FTTH on fibre broadband connections started working in BSNL Rajasthan. In BSNL Rajasthan from the 2006 to 2017 there was a $25.04 \%$ compounded annual growth(CAGR) in combined ADSL broadband connections and FTTH connections and number of both these technologies connections increased from 20045 to 234188.

- In BSNL Rajasthan from the 2006 to 2017 there was a $55.86 \%$ compounded annual growth(CAGR) in combined ADSL BB FTTH capacity and this capacity increased from 26524 to 484224.

- In BSNL Rajasthan from the 2009 to 2017 there was a $12.39 \%$ compounded annual growth(CAGR) in combined ADSL BB and FTTH revenue and this revenue increased from $108.80 \mathrm{Cr}$ to $246.40 \mathrm{Cr}$. More marketing efforts required to popularize the FTTH services to load and utilize the capacity of FTTH available.

Table 3-Status of different services Rajasthan as on

\begin{tabular}{|c|c|c|c|c|c|c|c|c|}
\hline S.N. & Item & Mar,06 & Mar,07 & Mar,08 & Mar,09 & \multicolumn{2}{|l|}{ Mar,10 } & Mar,11 \\
\hline 1 & $\begin{array}{l}\mathrm{LL} \\
\mathrm{DEL}\end{array}$ & 1745491 & 1656183 & 1551432 & 1480889 & 1414030 & & 545 \\
\hline 2 & Pop(Cr) & 5.6473122 & 5.6473122 & 5.6473122 & 5.6473122 & 5.647312 & & 3122 \\
\hline S.N. & Item & Mar,12 & Mar,13 & Mar,14 & "Mar,15 & Mar,16 & Mar,17 & $\begin{array}{l}\text { CAGR } \\
\text { in \% }\end{array}$ \\
\hline 1 & $\begin{array}{l}\mathrm{LL} \\
\text { DEL }\end{array}$ & 980463 & 883108 & 795966 & 687869 & 646449 & 611237 & $-9.10 \%$ \\
\hline 2 & Pop(Cr) & 7.3529325 & 7.3529325 & 7.3529325 & 7.3529325 & 7.3529325 & 7.3529325 & $2.43 \%$ \\
\hline
\end{tabular}


Table 4:- Status of Wireless services Rajasthan as on

\begin{tabular}{|c|c|c|c|c|c|c|c|c|}
\hline S.N. & Item & Mar,06 & Mar,07 & Mar,08 & \multicolumn{2}{|l|}{ Mar,09 } & Mar,10 & Mar,11 \\
\hline 1 & WLL DEL & 227420 & 230320 & 278739 & 341978 & \multicolumn{2}{|c|}{405303} & 281654 \\
\hline 2 & GSM & 1099415 & \multirow{2}{*}{$\begin{array}{l}2051224 \\
2281544\end{array}$} & 2278150 & \multirow{2}{*}{$\begin{array}{l}3572890 \\
3914868\end{array}$} & \multicolumn{2}{|c|}{4098819} & 5423896 \\
\hline \multicolumn{2}{|c|}{$\begin{array}{l}\text { Total Wireless } \\
\text { Connections }\end{array}$} & 1326835 & & 2556889 & & 4504 & & 5705550 \\
\hline S.N. & Item & Mar,12 & Mar,13 & Mar,14 & Mar,15 & Mar,16 & Mar,17 & $\begin{array}{l}\text { CAGR in } \\
\%\end{array}$ \\
\hline 1 & $\begin{array}{l}\text { WLL } \\
\text { DEL }\end{array}$ & 160985 & 129338 & 108463 & 91398 & 71551 & 57461 & $-11.76 \%$ \\
\hline 2 & GSM & 5722733 & 5788422 & 5902115 & 3160554 & 3427377 & 5469181 & $15.70 \%$ \\
\hline $\begin{array}{l}\text { Total } \\
\text { Conn }\end{array}$ & $\begin{array}{l}\text { Wireless } \\
\text { ctions }\end{array}$ & 5883718 & 5917760 & 6010578 & 3251952 & 3498928 & 5526642 & $13.85 \%$ \\
\hline
\end{tabular}

Table 5:-Status of combined BB \& FTTH services Rajasthan as on

\begin{tabular}{|c|c|c|c|c|c|c|c|c|}
\hline S.N. & Item & Mar,06 & \begin{tabular}{|l|} 
Mar,08 \\
81516
\end{tabular} & \multicolumn{2}{|c|}{ Mar,08 } & Mar,09 & Mar,10 & Mar,11 \\
\hline 1 & BB Conn & 20045 & 26493 & \multirow{2}{*}{\multicolumn{2}{|c|}{$\begin{array}{l}81546 \\
0\end{array}$}} & 128082 & 180742 & 195064 \\
\hline \multirow[t]{2}{*}{2} & FTTH Conn & 0 & 0 & & & 0 & 53 & 517 \\
\hline & Total Conn & 20045 & 26493 & \multicolumn{2}{|l|}{81546} & 128082 & 180795 & 195581 \\
\hline 3 & BB-Rev- Cr & 0 & 0 & \multicolumn{2}{|l|}{0} & 0 & 108.8 & 118.46 \\
\hline \multirow[t]{2}{*}{4} & FTTH Rev-Cr & 0 & 0 & \multicolumn{2}{|l|}{0} & 0 & 0 & 0 \\
\hline & Total Rev-Cr & 0 & 0 & \multicolumn{2}{|c|}{0} & 0 & 108.8 & 118.46 \\
\hline 5 & BB Cap & 26524 & 34552 & \multicolumn{2}{|c|}{151612} & 228016 & 228016 & 360640 \\
\hline \multirow[t]{2}{*}{6} & FTTH Cap & 0 & 0 & \multicolumn{2}{|c|}{0} & 0 & 45043 & 45248 \\
\hline & Total Cap & 26524 & 34552 & \multicolumn{2}{|c|}{151612} & 228016 & 273059 & 405888 \\
\hline 7 & $\begin{array}{l}\text { BB City \& } \\
\text { Exchanges }\end{array}$ & 15 & 23 & \multicolumn{2}{|c|}{51} & 253 & 760 & 1929 \\
\hline S.N. & Item & Mar,12 & Mar,13 & Mar,14 & Mar,15 & Mar,16 & "Mar,17 & $\begin{array}{l}\text { CAGR } \\
\text { in \% }\end{array}$ \\
\hline 1 & BB Conn & 202843 & 210803 & 212381 & 207300 & 222291 & 225271 & $24.60 \%$ \\
\hline 2 & FTTH Conn & 929 & 1416 & 2356 & 3346 & 6284 & 8917 & $107.97 \%$ \\
\hline & Total Conn & 203772 & 212219 & 214737 & 210646 & 228575 & 234188 & $25.04 \%$ \\
\hline 3 & BB-Rev-Cr & 147.85 & 158.1 & 178.63 & 193.86 & 213.98 & 229.72 & $11.27 \%$ \\
\hline 4 & FTTH Rev-Cr & 1.69 & 2.83 & 3.9 & 6.04 & 9.98 & 16.68 & $58.07 \%$ \\
\hline & Total Rev-Cr & 149.54 & 160.93 & 182.53 & 199.9 & 223.96 & 246.4 & $12.39 \%$ \\
\hline 5 & BB Cap & 378624 & 394448 & 428112 & 438976 & 438976 & 438976 & $29.06 \%$ \\
\hline 6 & FTTH Cap & 45248 & 45248 & 45248 & 45248 & 45248 & 45248 & $0.06 \%$ \\
\hline & Total Cap & 423872 & 439696 & 473360 & 484224 & 484224 & 484224 & $30.22 \%$ \\
\hline 7 & $\begin{array}{l}\text { BB City \& } \\
\text { Exchanges }\end{array}$ & 1930 & 1938 & 1948 & 1958 & 1978 & 1978 & $55.86 \%$ \\
\hline
\end{tabular}

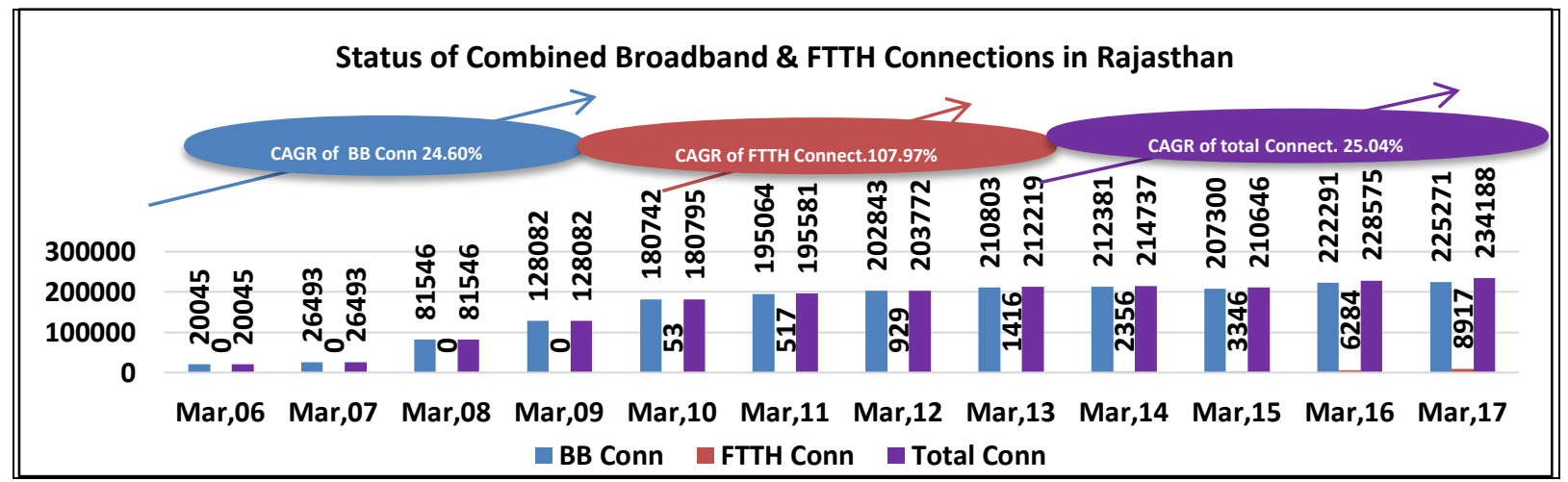

Fig 2: - Status of Combined BB \& FTTH Connections in Rajasthan 


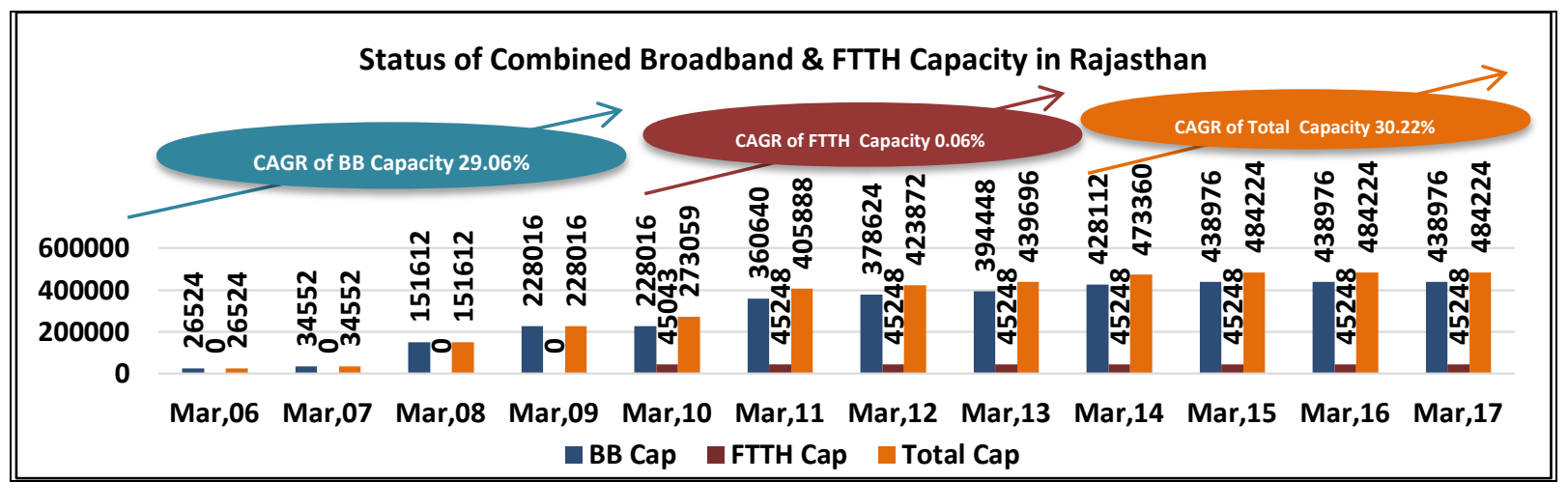

Fig 3: - Status of Combined BB \& FTTH Capacity in Rajasthan

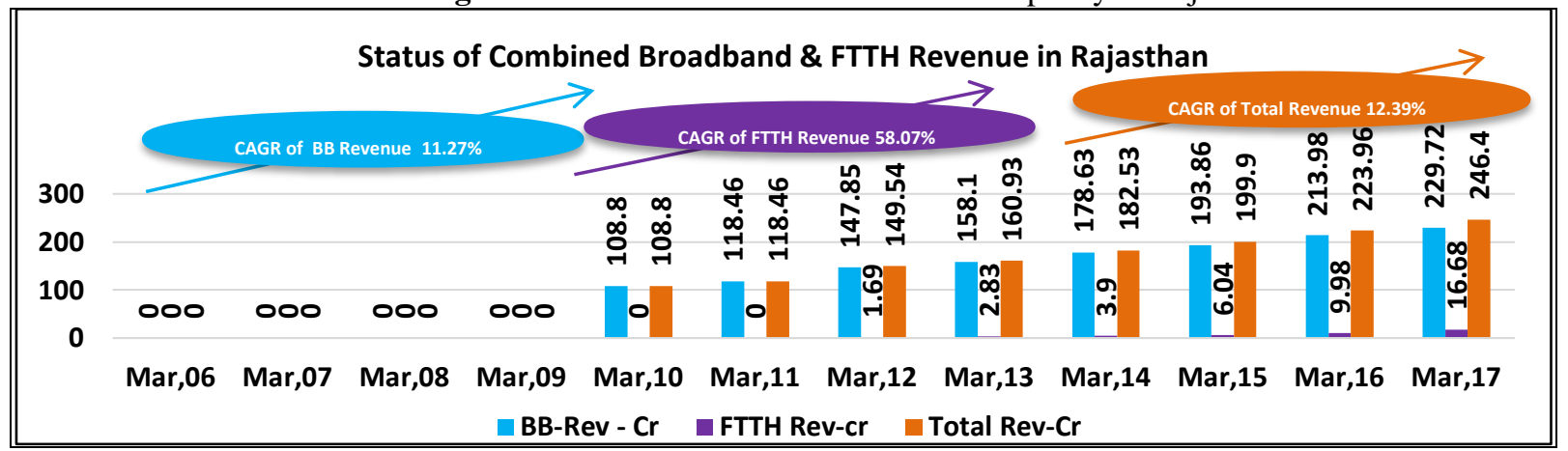

Fig 4: - Status of Combined BB \& FTTH Revenue (in Cr.) in Rajasthan

3.1b- BB \&FTTH Growth of Average connections, ABF and Revenue recovery: -

- The compounded annual growth rate of average combined broadband and FTTH connections (CAGR in \%) for the period 2009-10 to 2016-17 was maximum in Jhunjhunu (19.98\%) followed by Sriganganagar (12.11\%), Bhilwara, Kota followed by other SSA's during this period. The overall total CAGR in \% in broadband connections of Rajasthan was 8.05\% during the period from 2009 to 2017

- The compounded annual growth rate of broadband and FTTH combined ABF (CAGR in \%) for the period 2009-10 to 2016-17 was maximum in Jhunjhunu (27.31\%) followed by Bhilwara (18.19\%), Sriganganagar (15.54\%) followed by other SSA's during this period. The overall total CAGR in \% in broadband and FTTH connections of Rajasthan was $12.19 \%$ during the period from 2009 to 2017

- The compounded annual growth rate of broadband and FTTH combined revenue recovery (CAGR in \%)for the period 2009-10 to 2016-17 was maximum in Jhunjhunu (26.11\%) followed by Bhilwara(16.86\%), Sriganganagar(15.73\%) followed by other SSA's during this period. The overall total CAGR in \% in broadband connections of Rajasthan was 12.39\% during the period from 2009 to 2017.

Table 6:- Growth of Combined BB \& FTTH (in \%)

\begin{tabular}{|c|c|c|c|c|c|c|c|c|c|c|c|c|}
\hline \multirow{3}{*}{ SSA } & \multicolumn{3}{|c|}{ BB + FTTH } & \multicolumn{3}{|c|}{ BB + FTTH } & \multicolumn{3}{|c|}{ Total Growth } & \multicolumn{3}{|c|}{ CAGR } \\
\hline & \multicolumn{3}{|c|}{ 2009-10 } & \multicolumn{3}{|c|}{ 2016-17 } & \multicolumn{3}{|c|}{ in \% } & \multicolumn{3}{|c|}{ CAGR in \% } \\
\hline & $\begin{array}{l}\text { AVG } \\
\text { o No } \\
\text { of } \\
\text { Con } \\
\text { ns }\end{array}$ & $\mathbf{A B F}$ & REC & $\begin{array}{l}\text { AVG } \\
\text { o No } \\
\text { of } \\
\text { Con } \\
\text { ns }\end{array}$ & $\mathbf{A B F}$ & REC & $\begin{array}{l}\text { AVG. } \\
\text { No of } \\
\text { Conns }\end{array}$ & $\mathbf{A B F}$ & REC & $\begin{array}{l}\text { AVG. } \\
\text { No of } \\
\text { Conn } \\
\text { s }\end{array}$ & $\mathbf{A B F}$ & REC \\
\hline AJM & 8340 & 71697 & 72310 & $\begin{array}{l}1513 \\
6\end{array}$ & $\begin{array}{l}15492 \\
8\end{array}$ & $\begin{array}{l}15604 \\
4\end{array}$ & $\begin{array}{l}81.49 \\
\%\end{array}$ & $\begin{array}{l}116.09 \\
\%\end{array}$ & $\begin{array}{l}115.80 \\
\%\end{array}$ & $8.89 \%$ & $\begin{array}{l}11.64 \\
\%\end{array}$ & $\begin{array}{l}11.61 \\
\%\end{array}$ \\
\hline ALW & 4559 & 44999 & 44470 & 8166 & $\begin{array}{l}10378 \\
3\end{array}$ & 94916 & $\begin{array}{l}79.12 \\
\%\end{array}$ & $\begin{array}{l}130.63 \\
\%\end{array}$ & $\begin{array}{l}113.44 \\
\%\end{array}$ & $8.68 \%$ & $\begin{array}{l}12.68 \\
\%\end{array}$ & $\begin{array}{l}11.44 \\
\%\end{array}$ \\
\hline
\end{tabular}




\begin{tabular}{|c|c|c|c|c|c|c|c|c|c|c|c|c|}
\hline BSW & 1418 & 13360 & 12616 & 2314 & 20333 & 22637 & $\begin{array}{l}63.19 \\
\%\end{array}$ & $\begin{array}{l}52.19 \\
\%\end{array}$ & $\begin{array}{l}79.43 \\
\%\end{array}$ & $7.25 \%$ & $\begin{array}{l}6.18 \\
\%\end{array}$ & $\begin{array}{l}8.71 \\
\%\end{array}$ \\
\hline$\overline{B M R}$ & 1095 & 10281 & 10000 & 1472 & 15167 & 17373 & $\begin{array}{l}34.43 \\
\%\end{array}$ & $\begin{array}{l}47.52 \\
\%\end{array}$ & $\begin{array}{l}73.73 \\
\%\end{array}$ & $4.32 \%$ & $\begin{array}{l}5.71 \\
\%\end{array}$ & $\begin{array}{l}8.21 \\
\%\end{array}$ \\
\hline BTP & 2034 & 16825 & 15899 & 1790 & 15011 & 19139 & $\begin{array}{l}- \\
12.00 \\
\%\end{array}$ & $\begin{array}{l}- \\
10.78 \\
\%\end{array}$ & $\begin{array}{l}20.38 \\
\%\end{array}$ & $\overline{-}-1.81 \%$ & $\begin{array}{l}- \\
1.62 \\
\%\end{array}$ & $\begin{array}{l}2.69 \\
\%\end{array}$ \\
\hline BHL & 4284 & 29478 & 30659 & 9037 & 94945 & 91225 & $\begin{array}{l}110.95 \\
\%\end{array}$ & $\begin{array}{l}222.09 \\
\%\end{array}$ & $\begin{array}{l}197.55 \\
\%\end{array}$ & $\begin{array}{l}11.25 \\
\%\end{array}$ & $\begin{array}{l}18.19 \\
\%\end{array}$ & $\begin{array}{l}16.86 \\
\%\end{array}$ \\
\hline BIK & 5896 & 49842 & 49520 & 9716 & $\begin{array}{l}10020 \\
4\end{array}$ & 96121 & $\begin{array}{l}64.79 \\
\%\end{array}$ & $\begin{array}{l}101.04 \\
\%\end{array}$ & $\begin{array}{l}94.11 \\
\%\end{array}$ & $7.40 \%$ & $\begin{array}{l}10.49 \\
\%\end{array}$ & $\begin{array}{l}9.94 \\
\%\end{array}$ \\
\hline BND & 662 & 5025 & 4979 & 1002 & 9587 & 10088 & $\begin{array}{l}51.36 \\
\%\end{array}$ & $\begin{array}{l}90.79 \\
\%\end{array}$ & $\begin{array}{l}102.61 \\
\%\end{array}$ & $6.10 \%$ & $\begin{array}{l}9.67 \\
\%\end{array}$ & $\begin{array}{l}10.61 \\
\%\end{array}$ \\
\hline CTT & 2468 & 19530 & 19089 & 2559 & 23064 & 25648 & $3.69 \%$ & $\begin{array}{l}18.10 \\
\%\end{array}$ & $\begin{array}{l}34.36 \\
\%\end{array}$ & $0.52 \%$ & $\begin{array}{l}2.40 \\
\%\end{array}$ & $\begin{array}{l}4.31 \\
\%\end{array}$ \\
\hline CRU & 1481 & 13426 & 13071 & 2168 & 17858 & 20374 & $\begin{array}{l}46.39 \\
\%\end{array}$ & $\begin{array}{l}33.01 \\
\%\end{array}$ & $\begin{array}{l}55.87 \\
\%\end{array}$ & $5.60 \%$ & $\begin{array}{l}4.16 \\
\%\end{array}$ & $\begin{array}{l}6.55 \\
\%\end{array}$ \\
\hline JP & $\begin{array}{l}4711 \\
9\end{array}$ & $\begin{array}{l}37747 \\
6\end{array}$ & $\begin{array}{l}36069 \\
2\end{array}$ & $\begin{array}{l}7192 \\
2\end{array}$ & $\begin{array}{l}84236 \\
9\end{array}$ & $\begin{array}{l}82839 \\
1\end{array}$ & $\begin{array}{l}52.64 \\
\%\end{array}$ & $\begin{array}{l}123.16 \\
\%\end{array}$ & $\begin{array}{l}129.67 \\
\%\end{array}$ & $6.23 \%$ & $\begin{array}{l}12.15 \\
\%\end{array}$ & $\begin{array}{l}12.61 \\
\%\end{array}$ \\
\hline JSM & 814 & 8163 & 8039 & 1074 & 12040 & 12803 & $\begin{array}{l}31.94 \\
\%\end{array}$ & $\begin{array}{l}47.49 \\
\%\end{array}$ & $\begin{array}{l}59.26 \\
\%\end{array}$ & $4.04 \%$ & $\begin{array}{l}5.71 \\
\%\end{array}$ & $\begin{array}{l}6.87 \\
\%\end{array}$ \\
\hline JLW & 888 & 8035 & 7828 & 1546 & 14913 & 15902 & $\begin{array}{l}74.10 \\
\%\end{array}$ & $\begin{array}{l}85.60 \\
\%\end{array}$ & $\begin{array}{l}103.14 \\
\%\end{array}$ & $8.24 \%$ & $\begin{array}{l}9.24 \\
\%\end{array}$ & $\begin{array}{l}10.66 \\
\%\end{array}$ \\
\hline JJN & 2280 & 15589 & 15367 & 8159 & 84493 & 77958 & $\begin{array}{l}257.85 \\
\%\end{array}$ & $\begin{array}{l}442.00 \\
\%\end{array}$ & $\begin{array}{l}407.31 \\
\%\end{array}$ & $\begin{array}{l}19.98 \\
\%\end{array}$ & $\begin{array}{l}27.31 \\
\%\end{array}$ & $\begin{array}{l}26.11 \\
\%\end{array}$ \\
\hline JPR & $\begin{array}{l}1414 \\
4\end{array}$ & $\begin{array}{l}13393 \\
3\end{array}$ & $\begin{array}{l}13272 \\
7\end{array}$ & $\begin{array}{l}2669 \\
7\end{array}$ & $\begin{array}{l}30188 \\
7\end{array}$ & $\begin{array}{l}29615 \\
5\end{array}$ & $\begin{array}{l}88.75 \\
\%\end{array}$ & $\begin{array}{l}125.40 \\
\%\end{array}$ & $\begin{array}{l}123.13 \\
\%\end{array}$ & $9.50 \%$ & $\begin{array}{l}12.31 \\
\%\end{array}$ & $\begin{array}{l}12.15 \\
\%\end{array}$ \\
\hline $\begin{array}{l}\text { KOT } \\
\text { A }\end{array}$ & 9499 & 77571 & 76543 & $\begin{array}{l}1934 \\
2\end{array}$ & $\begin{array}{l}19166 \\
8\end{array}$ & $\begin{array}{l}18743 \\
7\end{array}$ & $\begin{array}{l}103.62 \\
\%\end{array}$ & $\begin{array}{l}147.09 \\
\%\end{array}$ & $\begin{array}{l}144.88 \\
\%\end{array}$ & $\begin{array}{l}10.69 \\
\%\end{array}$ & $\begin{array}{l}13.79 \\
\%\end{array}$ & $\begin{array}{l}13.65 \\
\%\end{array}$ \\
\hline NGR & 1811 & 13515 & 13458 & 3005 & 25082 & 28006 & $\begin{array}{l}65.93 \\
\%\end{array}$ & $\begin{array}{l}85.59 \\
\%\end{array}$ & $\begin{array}{l}108.10 \\
\%\end{array}$ & $7.50 \%$ & $\begin{array}{l}9.24 \\
\%\end{array}$ & $\begin{array}{l}11.04 \\
\%\end{array}$ \\
\hline PLI & 2545 & 18807 & 18725 & 4141 & 35854 & 38572 & $\begin{array}{l}62.71 \\
\%\end{array}$ & $\begin{array}{l}90.64 \\
\%\end{array}$ & $\begin{array}{l}105.99 \\
\%\end{array}$ & $7.20 \%$ & $\begin{array}{l}9.66 \\
\%\end{array}$ & $\begin{array}{l}10.88 \\
\%\end{array}$ \\
\hline SWM & 1387 & 11120 & 11082 & 1960 & 17560 & 19657 & $\begin{array}{l}41.31 \\
\%\end{array}$ & $\begin{array}{l}57.91 \\
\%\end{array}$ & $\begin{array}{l}77.38 \\
\%\end{array}$ & $5.06 \%$ & $\begin{array}{l}6.74 \\
\%\end{array}$ & $\begin{array}{l}8.53 \\
\%\end{array}$ \\
\hline SIK & 2225 & 19869 & 18532 & 3111 & 29662 & 31230 & $\begin{array}{l}39.82 \\
\%\end{array}$ & $\begin{array}{l}49.29 \\
\%\end{array}$ & $\begin{array}{l}68.52 \\
\%\end{array}$ & $4.90 \%$ & $\begin{array}{l}5.89 \\
\%\end{array}$ & $\begin{array}{l}7.74 \\
\%\end{array}$ \\
\hline SRO & 1750 & 16165 & 15763 & 3241 & 29479 & 33060 & $\begin{array}{l}85.20 \\
\%\end{array}$ & $\begin{array}{l}82.36 \\
\%\end{array}$ & $\begin{array}{l}109.73 \\
\%\end{array}$ & $9.20 \%$ & $\begin{array}{l}8.96 \\
\%\end{array}$ & $\begin{array}{l}11.16 \\
\%\end{array}$ \\
\hline SGR & 6149 & 44189 & 43451 & $\begin{array}{l}1368 \\
8\end{array}$ & $\begin{array}{l}12144 \\
7\end{array}$ & $\begin{array}{l}12079 \\
6\end{array}$ & $\begin{array}{l}122.61 \\
\%\end{array}$ & $\begin{array}{l}174.84 \\
\%\end{array}$ & $\begin{array}{l}178.01 \\
\%\end{array}$ & $\begin{array}{l}12.11 \\
\%\end{array}$ & $\begin{array}{l}15.54 \\
\%\end{array}$ & $\begin{array}{l}15.73 \\
\%\end{array}$ \\
\hline TNK & 994 & 7362 & 7198 & 1427 & 13124 & 14534 & $\begin{array}{l}43.56 \\
\%\end{array}$ & $\begin{array}{l}78.27 \\
\%\end{array}$ & $\begin{array}{l}101.92 \\
\%\end{array}$ & $5.30 \%$ & $\begin{array}{l}8.61 \\
\%\end{array}$ & $\begin{array}{l}10.56 \\
\%\end{array}$ \\
\hline UPR & $\begin{array}{l}1094 \\
9\end{array}$ & 85539 & 85998 & $\begin{array}{l}1903 \\
7\end{array}$ & $\begin{array}{l}21236 \\
8\end{array}$ & $\begin{array}{l}20592 \\
9\end{array}$ & $\begin{array}{l}73.87 \\
\%\end{array}$ & $\begin{array}{l}148.27 \\
\%\end{array}$ & $\begin{array}{l}139.46 \\
\%\end{array}$ & $8.22 \%$ & $\begin{array}{l}13.87 \\
\%\end{array}$ & $\begin{array}{l}13.29 \\
\%\end{array}$ \\
\hline $\begin{array}{l}\text { TOT } \\
\text { AL }\end{array}$ & $\begin{array}{l}1347 \\
89 \\
\end{array}$ & $\begin{array}{l}11117 \\
96\end{array}$ & $\begin{array}{l}10880 \\
16\end{array}$ & $\begin{array}{l}2317 \\
10\end{array}$ & $\begin{array}{l}24868 \\
26\end{array}$ & $\begin{array}{l}24639 \\
95\end{array}$ & $\begin{array}{l}71.91 \\
\%\end{array}$ & $\begin{array}{l}123.68 \\
\%\end{array}$ & $\begin{array}{l}126.47 \\
\%\end{array}$ & $\begin{array}{l}8.05 \\
\%\end{array}$ & $\begin{array}{l}12.19 \\
\%\end{array}$ & $\begin{array}{l}12.39 \\
\%\end{array}$ \\
\hline
\end{tabular}




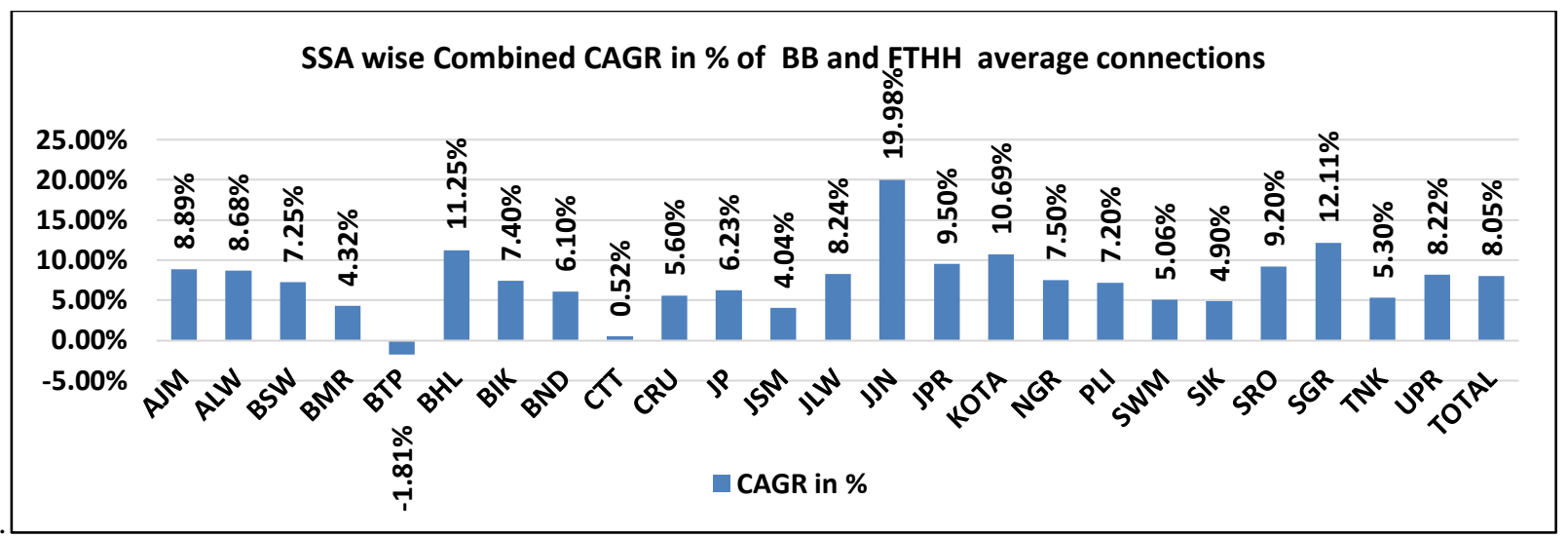

Fig 5: - SSA wise Combined CAGR (in \%) of BB and FTHH average connections

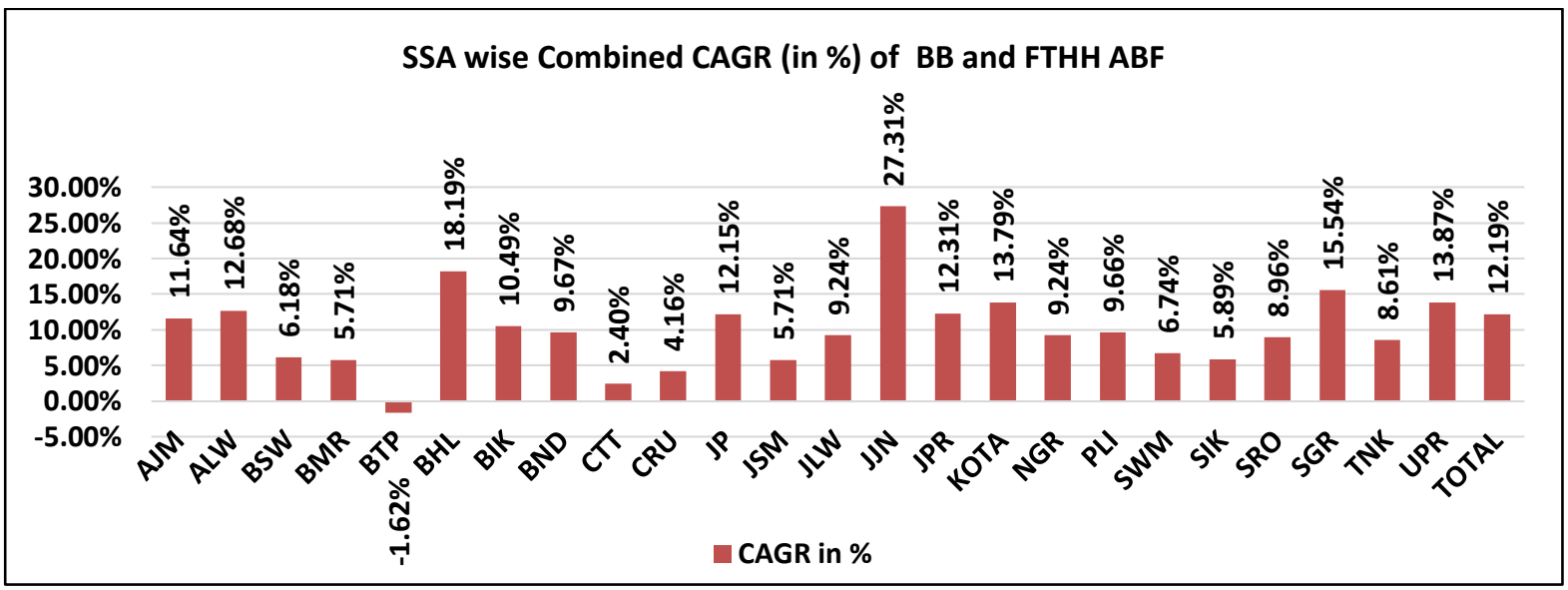

Fig 6: - SSA wise Combined CAGR (in \%) of BB and FTHH ABF

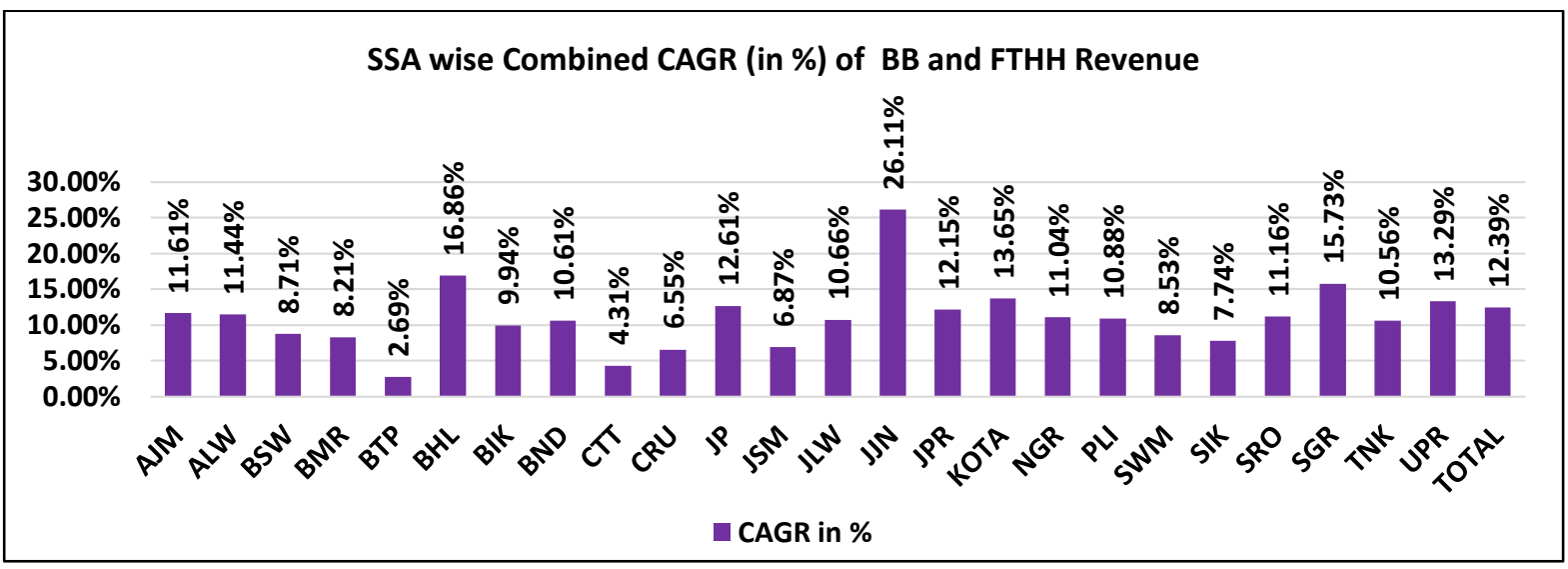

Fig 7:-SSA wise Combined CAGR (in \%) of BB and FTHH Revenue

\subsection{Interpretation of results of tabulation:}

$>$ Table 2- Growth in total subscribers, wireless, Broadband and Tele-density total and wireless Tele-density:

> Fig 1: - Growth in subscribers, Tele-Density \& Revenue \& Broadband Connections: - At national level in India from the 2007 to 2017 there was a $19.22 \%$ compounded annual growth (CAGR) in telecom connections and number of connections increased from 205.86 million to 1194.58 million. There was a $21.64 \%$ compounded annual growth (CAGR) in telecom wireless connections and number of wireless connections increased from 165.00 million to 1170.00 million. Growth in total Tele Density (per 100 population) and wireless Tele-density: In India from the 2007 to 2017 there was a $20.34 \%$ compounded annual growth(CAGR) in total Tele-density 
and Tele-density increased from 14.60 (per 100 populations) to 92.98 (per 100 populations). During this period there was a $20.09 \%$ compounded annual growth(CAGR) in wireless Tele-density and wireless Tele-density increased from 14.60 (per 100 populations) to 91.08 (per 100 populations). Telecom Sector Revenue (USD Billion): - In India from the 2007 to 2017 there was a $5.34 \%$ compounded annual growth(CAGR) in total Teledensity and Tele-density increased from 23.30 (USD Billions) to 39.20 (USD Billions)

$>$ Table 3-Status of different services Rajasthan: -Status of Landline services Rajasthan: There was a decline in wired line connections of BSNL Rajasthan by $65 \%$. This was due to the fact that there was a churn from land line connections to mobile connections. The compounded annual growth rate was $-9.10 \%$

$>$ Table 4 -Status of Wireless services Rajasthan: Status of Wireless services Rajasthan: There was a 316\% growth in wireless connections of BSNL Rajasthan. These include CDMA \& GSM connections. There was a sharp decline in the wireless connections in 2014-15 and 2015-016 (March ending). This was due to disconnections of CDMA customers and purging of inactive mobile connections. The CAGR of wireless connections in Rajasthan was observed as $13.85 \%$.

$>$ Table 5 -Status of combined Broadband \& FTTH services Rajasthan:

- Status of Broadband Connections in Rajasthan: :-In BSNL Rajasthan from the 2006 to 2017 there was a 24.60 $\%$ compounded annual growth(CAGR) in ADSL broadband connections and number of ADSL broadband connections increased from 20045 to 225271.

- Status of Broadband Capacity in Rajasthan: In BSNL Rajasthan from the 2006 to 2017 there was a $29.06 \%$ compounded annual growth(CAGR) in ADSL broadband capacity and capacity of ADSL broadband lines increased from 26524 to 438976

- Status of Broadband Revenue (in Cr.) in Rajasthan: In BSNL Rajasthan from the 2006 to 2017 there was a $11.27 \%$ compounded annual growth(CAGR) in ADSL broadband revenue and ADSL broadband revenue increased from 108.8 $\mathrm{Cr}$ to $229.72 \mathrm{Cr}$. Since commissioning of ADSL broadband services in BSNL Rajasthan in 2005 till 2009 the revenue of these services were counted in land line revenues and in 2010 the revenue of BB services was bifurcated. This was emerged as a new revenue stream for BSNL and acted as bread and butter for BSNL as land line was continuously getting churned in mobile services. To some extent BB services stopped the churning of land line connections

- Status of FTTH Connections in Rajasthan: In 2009-10 the FTTH service started on optical fibre for providing broadband connections on fibre. In BSNL Rajasthan from the 2010 to 2017 there was a $107.97 \%$ compounded annual growth(CAGR) in FTTH connections and FTTH connections increased from 53 to 8917. This has helped BSNL to provide connections on optical fibre rather than land line local loop. This reduced the local loop loses and their-by increased the stability of broadband connection as well as increased the broadband speed.

- Status of FTTH Capacity in Rajasthan: In BSNL Rajasthan from the 2010 to 2017 there was a $0.06 \%$ compounded annual growth(CAGR) in FTTH capacity and FTTH capacity was more or less remained same to 45248 as there was lot of efforts required by BSNL for providing FTTH connections and initial capacity was not utilized so far.

- Status of FTTH Revenue (in Cr.) in Rajasthan: In BSNL Rajasthan from the 2009 to 2017 there was a $58.07 \%$ compounded annual growth (CAGR) in FTTH revenue and this revenue increased from $1.69 \mathrm{Cr}$ to $16.68 \mathrm{Cr}$. Since commissioning of FTTH services in BSNL Rajasthan in 2009 till 2011 the revenue of these services were counted negligible as it did not pick up initially. In 2012 the revenue of FTTH services was bifurcated. This was emerged as a new revenue stream for BSNL. More marketing efforts required to popularize these services.

- Fig 2: - Status of Combined BB \& FTTH Connections in Rajasthan: -Now two types of technology, one was ADSL BB and other FTTH on fibre broadband connections started working in BSNL Rajasthan. In BSNL Rajasthan from the 2006 to 2017 there was a $25.04 \%$ compounded annual growth(CAGR) in combined ADSL broadband connections and FTTH connections and number of both these technologies connections increased from 20045 to 234188.

- $\quad$ Fig 3: - Status of Combined BB \& FTTH Capacity in Rajasthan: In BSNL Rajasthan from the 2006 to 2017 there was a $55.86 \%$ compounded annual growth(CAGR) in combined ADSL BB FTTH capacity and this capacity increased from 26524 to 484224 .

- Fig 4: - Status of Combined BB \& FTTH Revenue (in Cr.) in Rajasthan: In BSNL Rajasthan from the 2009 to 2017 there was a $12.39 \%$ compounded annual growth(CAGR) in combined ADSL BB and FTTH revenue and this revenue increased from $108.80 \mathrm{Cr}$ to $246.40 \mathrm{Cr}$. More marketing efforts required to popularize the FTTH services to load and utilize the capacity of FTTH available.

$>$ Table 6: Growth of Combined BB \& FTTH (in \%)

- Fig 5: - SSA wise Combined CAGR (in \%) of BB and FTHH average connections- The compounded annual growth rate of average combined broadband and FTTH connections (CAGR in \%) was maximum in Jhunjhunu 
(19.98\%) followed by Sriganganagar(12.11\%), Bhilwara, Kota followed by other SSA's during this period. The overall total CAGR in \% in broadband connections of Rajasthan was $8.05 \%$ during the period from 2009 to 2017

- Fig 6: - SSA wise Combined CAGR (in \%) of BB and FTHH ABF- The compounded annual growth rate of broadband and FTTH combined ABF (CAGR in \%) was maximum in Jhunjhunu (27.31\%) followed by Bhilwara (18.19\%), Sriganganagar (15.54\%) followed by other SSA's during this period. The overall total CAGR in $\%$ in broadband and FTTH connections of Rajasthan was $12.19 \%$ during the period from 2009 to 2017

- Fig 7: SSA wise Combined CAGR (in \%) of BB and FTHH Revenue- The compounded annual growth rate of broadband and FTTH combined revenue recovery (CAGR in \%) was maximum in Jhunjhunu (26.11\%) followed by Bhilwara (16.86\%), Sriganganagar(15.73\%) followed by other SSA's during this period. The overall total CAGR in \% in broadband connections of Rajasthan was $12.39 \%$ during the period from 2009 to 2017.

3.3 Marketing strategies: - In the initial phases of induction and adoption of ADSL based broadband services lot of marketing efforts were put due to less knowledge of personal computers, low availability of pc's in the market specially in rural area and the affordability of tariffs. BSNL Rajasthan adopted many strategies initially to boost the customer base. BSNL put lot of efforts to increase penetration of broadband services in rural exchanges. Few of Special plans adopted by BSNL were as follows:

- SMS sent on mobiles.

- Mailers sent along with telephone bills.

- Regular advertisements given in press \& radio.

- Coverage given in press conferences.

- Demos at CSCs (Customer Service Centre).

- $20 \%$ discount to Govt. employees. It was applicable to all Central/State Govt. / PSU employees/ Govt. added school/ college employees and such retired employees.

- Special plan for Rural areas with Installation, Registration and Modem free: i. Rural plan 99 with $400 \mathrm{Mb}$ free for Monthly rental of Rs 99/ii. Rural plan 150 with 1 GB free for Monthly rental of Rs150.

- Bundling scheme of PC's in rural areas where MOU was signed with PC venders like M/s HCL and M/s Novatium. M/s Novatium offered with/without hard disk connected with server located at Chennai ,1900/upfront payment ,175/-EMI and 150/- plan charges. M/s HCL offered with full PC with 4500/- upfront payment and, with 3 \& 5 years of 455/ - EMI. And 300/- EMI. With these schemes around 700 PC's were inducted in rural area broadband connections.

- Project Udaan was launched for the lead generation of broadband connections which was a very successful scheme.

- Broadband kiosks were provided in almost all SDCA's. (Short distance Charging areas)

- VPN BB connections were provided in the colleges covering 700 colleges

- Under NMEICT project of ministry of HRD 50 universities were connected with 1 GBPS links

- Deployed broadband rural public services terminal (RPST) and provisioned INDEPLAY services for women self-help groups (WSHG) with USO subsidy.

- Start up plans of 250/- for both for business and residential consumers.

- Data-One home and business plans

- Combo plan 525 /750/-

- Voice and data combo plans 1199/- with unlimited use with speed restrictions.

- Plan wise details of FTTH Subscribers:-Out of 8673 as on 31.03.2017 consumers of FTTH services major consumers (954) were from FTTH combo 1199 monthly, (1300) from plan 900 monthly, (563) from UL1350 monthly, (328) from UL-499 monthly, (317) from UL-795 monthly, (344) from UL-625 monthly, (241) from UL-2841 monthly, (223) from UL-999 and others from other different plans.

3.4Reasons for disconnections of broadband connections: -- During initial stage of adoption and customer acquisition the reasons of disconnections of broadband connections were analysed. The reasons of disconnections were mainly (i) not more usable (14.23\%) followed by Closer of Free Trial (8.35\%), Not affordable (7.61\%), Landline Disconnection (1.11\%), Excess billing (1.03\%), Not satisfied with service $(0.02 \%)$ and other own reasons $(67.67 \%)$ 


\subsection{Factors responsible for the growth of BSNL ADSL based BB services in Rajasthan LSA.}

- Benefit of first entrant- The BSNL's ADSL based BB services in Rajasthan LSA were started in the Year 2005 and at that time there was no private operators in the field of providing broadband services on copper pair. Hence it added the advantages of first entrant which was the important factor in the growth of ADSL based broadband services of BSNL in Rajasthan

- Monopoly on local loop underground copper cable in Rajasthan there were three operators namely M/s Bharti Airtel, M/s RCL, M/s SSTL who were only providing services in Jaipur city and that too only in limited areas hence there was a monopoly in the copper pair local loop which was the main factor in the growth of ADSL based broadband services.

- PAN India and PAN Rajasthan presence: As evident from growth tables the broadband services were started in all the exchanges of BSNL Rajasthan including rural areas which gave boost to BSNL broadband growth.

- Experience man power: This factor enabled BSNL to implement the ADSL based broadband services throughout Rajasthan without difficulty

- $100 \%$ Government run PSU: Since BSNL has 100\% government control hence customers have faith in BSNL and its services which led to growth of broadband services.

- Transparency in working and tariffs: This factor also led to growth of BSNL's broadband services being a $100 \%$ government run company.

- The researcher having experience of telecom for more than 35 years was circle coordinator to implement the projects with proper planning and resource mobilizations.

- Many proactive schemes introduced like Project Udaan, PC bundling etc for enhancing the growth of Broadband services.

4. Future Prospects: BSNL broadband services have bright future though during the induction of broadband services many difficulties were faced by BSNL. With the induction of $3 \mathrm{G}, 4 \mathrm{G}$ and data services offered by Private telecom service providers there remains a tough competition but still the BSNL broadband considered as the most reliable internet connectivity. BSNL has to give more attention in the maintenance and support services to remain in competition of data services. The marketing strategies to be aggressive to combat with the cut throat competition.

5. Challenges: Unlike past, now a day each and every user wants uninterrupted and fast data transfer rates. Apps, social media platforms and web contents have become fatter in size. Old feature phones which support voice are disappearing at faster pace and may become history in time to come. Everyone from school going kid to professional need data services for their routine work. Even visiting shops has been replaced by online shopping to some extent and becoming popular day by day. Following important challenges were:

- Affordability for connectivity and device: As far as affordability for connectivity concerned, after cut throat competition in data tariffs the issue has more or less vanished. Now the main issue remains affordability of devices. Unlike the recent past now a day's broadband users have no dependency on desktop PC, Laptop or Tablets. Smart phone has emerged as an alternate. Data consumed by smart phone users have increased multi fold. This established with the fact that mobile data volume has increased by more than $450 \%$ in last few months. Although the prices of smart phones have gone down but for a common man smart phone affordability remains still an issue. An average cost of mid class smart phone remains still around Rs. 5000.00. Indian market especially mid-size cities and towns still remain cost sensitive.

\section{Suggestion:}

- If government support and provide some kind of financial relief in term of import duty, Taxes and other levies bridging the gap of digital divide may be at faster pace.

- Human Skill and Language: Human skill and language has noticed as second challenge. Issue of human skill can be developed as smart phones continue to be very user friendly and small session of 2 hours would help them to build confidence. But the language still remained barrier. Content in local language i.e either not available or availability very less and further the subject and topics covered by local language is minimal and not up to satisfaction of users.

\section{Suggestion:}

- E-Library in local language

- Translation of contents which were useful and informative for masses

- Making available dubbed audio in local language especially for Students, women and Farmers.

- Challenges to roll out services: After the tariff war in data services, it has become very difficult for operators to roll out services in newer area as capital cost has not reduced but revenue expected has gone down drastically. 
In order to offer guaranteed QoS, reliability and fast restoration, huge capital is required but return on capital is not guaranteed. Viability has become an issue for some operators which will lead to merger and acquisition of smaller operators with big players. Present scenario may be in favour of customers but after merger and acquisition competition will reduce and big players will play their game.

- The Digital divide of the growth story biased in favour of urban areas was another issue. DoT (Department of Telecom0 tried to boost the growth of broadband in rural areas by promoting higher investment in rural infrastructure and subsidized tariff for rural subscribers under Universal service obligation scheme of the Indian government.

- One of the major issue, the internet segment facing was the lower average bandwidth of broadband connections compared to that of developed countries.

- Hyper competition market and falling tariff regime.

- Strengthening of sales and distribution network

- Matching Coverage with private operators

- Legacy of Government department in the attitude of the staff.

6. Bottlenecks: Bottleneck runs parallel with challenges.

- High capital cost bandwidth and linear connectivity are bottleneck which directly affect the QoS.

- Technology has changed rapidly from $2 \mathrm{G}$ to $2.5 \mathrm{G}$ then $3 \mathrm{G}, 4 \mathrm{G}$, Wi-Fi in just 10 years' span. Equipment's becoming obsolete at a fast rate and recovery of investment in such tariff war scenario has become unprofitable and nonviable.

- Availability of copper as last mile connectivity remains major issue to provide connectivity and hence developed and developing areas have stopped copper cable laying due to high cost.

- $\quad$ FTTH being deployed to cover the areas where laying of copper cable not feasible but the laying of OF cable and providing connection remains costly affair hence for a customer seeking lowest plan (cheaper plan) becomes unviable. Practically the FTTH has benefit for high bandwidth users.

- Maintainability of ADSL broadband remained the issue and very high mean time to repair due to old staff of BSNL.

- Condition of local loop on copper pair affecting the QoS and the line losses and other parameters to give proper speed remains the issue.

- The main constraints in ubiquity were higher tariff of Internet usages, non-availability of last-mile broadband connectivity, non-availability of electricity, less awareness about e-Services and quality of services rendered.

- Due to constraints of marketing budget, visibility of BSNL affected adversely in comparison to private telecom service providers.

- After the induction of broadband service on fibre (FTTH-Fibre to the home) during 2009-2010 following bottlenecks/constraints observed.

$>$ The ONT available with BSNL was not Wi-Fi enable, subscriber has to arrange additional Modem/Router to make the ONT Wi-Fi enable.

$>$ Most of the roads in walled city were narrow and end to end concreted. Taking permission from local authorities and laying OFC in these areas was a very difficult task.

$>$ The battery sets, available with ONT for power back-up have been expired. Even after 7 years of launching, the FTTH services were not popular in public.

$>$ Most of the areas were still not feasible. BSNL needs to lay more OFC for making distribution network to make more area feasible for FTTH Connections.

$>$ The services were cost effective for providing connections in multi stories buildings.

$>$ Catering the demand in scattered area/individual buildings was not economic.

\section{Present Scenario:}

- In present scenario ADSL broadband over copper, FTTH, Wi-Fi hot spot and 3G/4G services have been serving the customers to meet their data service requirement. RJIL has launched the services under brand name JIO. The practice adopted to popularize his services has severely affected all operators. Free services launched for a prolonged period reflected in severe dent in data volume across the domain. None of the service provider remained unaffected and revenue and profit gone down for all operators. Such scenario has adversely affected the future plan due to negative trend in revenue and profit of all service providers. NPAs (Non-payment accounts) in telecom sector have rise and new flow of capital expenditure has seen a jerk. 
- The table no. 7 detailed about Revenue comparison of combined FTTH \& Broadband services for Q1-2016-17 \& Q1-2017-18 of BSNL Rajasthan. There was a reduction of $-6.39 \%$ in the total revenue compare to last year Q1 \& this year Q1. Previous year difference of revenue between Q1 2015-16 \& Q1 2016-17 was 17.39\%. Hence it was concluded that there was a serious impact (-6.39\% in place of $17.39 \%)$ on revenue collection of BB \& FTTH Services of BSNL in Rajasthan due to M/s RJIL the new entrant Telecom Service Provider. BSNL Rajasthan has to do aggressive marketing and adopt new strategies and technologies to combat with this situation.

Table no. 7:- Quarterly BB+FTTH Revenue comparison

\begin{tabular}{|c|c|c|c|c|c|c|c|c|}
\hline \multirow{2}{*}{$\begin{array}{l}\text { S. } \\
\text { No. }\end{array}$} & \multirow[t]{2}{*}{ SSA } & \multirow[t]{2}{*}{ SSA's details } & \multicolumn{2}{|c|}{ BB+FTTH-Q1-16 } & \multicolumn{2}{|c|}{ BB+FTTH-Q1-17 } & \multicolumn{2}{|c|}{ Difference } \\
\hline & & & $\begin{array}{l}\text { Amoun } \\
t \text { Billed } \\
\text { for }\end{array}$ & $\begin{array}{l}\text { Amount } \\
\text { Recovere } \\
\text { d }\end{array}$ & $\begin{array}{l}\text { Amoun } \\
t \text { Billed } \\
\text { for }\end{array}$ & $\begin{array}{l}\text { Amount } \\
\text { Recovere } \\
\text { d }\end{array}$ & $\begin{array}{l}\text { Amoun } \\
t \text { Billed } \\
\text { for }\end{array}$ & $\begin{array}{l}\text { Amount } \\
\text { Recovere } \\
\text { d }\end{array}$ \\
\hline 1 & Ajmer & AJM & 39226 & 38668 & 45522 & 35386 & $16.05 \%$ & $-8.49 \%$ \\
\hline 2 & Alwar & ALW \& BTP & 29062 & 28215 & 35657 & 27402 & $22.69 \%$ & $-2.88 \%$ \\
\hline 3 & Bhilwara & BHL \& CTT & 30071 & 29191 & 35503 & 27089 & $18.07 \%$ & $-7.20 \%$ \\
\hline 4 & Bikaner & BIK \& NGR & 31479 & 31066 & 37502 & 28067 & $19.13 \%$ & $-9.65 \%$ \\
\hline 5 & Jaipur & JP, SWM \& TNK & 223591 & 217427 & 263512 & 207253 & $17.85 \%$ & $-4.68 \%$ \\
\hline 6 & Jhunjhunu & JJN, CRU \& SIK & 33407 & 31669 & 40847 & 30852 & $22.27 \%$ & $-2.58 \%$ \\
\hline 7 & Jodhpur & $\begin{array}{l}\text { JPR, BMR, JSM \& } \\
\text { PLI }\end{array}$ & 93120 & 91426 & 108407 & 84792 & $16.42 \%$ & $-7.26 \%$ \\
\hline 8 & Kota & KOTA, BND \& JLW & 55160 & 53961 & 61906 & 48136 & $12.23 \%$ & $-10.79 \%$ \\
\hline 9 & $\begin{array}{l}\text { Sriganganag } \\
\text { ar }\end{array}$ & SGR & 29738 & 29436 & 36891 & 28653 & $24.05 \%$ & $-2.66 \%$ \\
\hline \multirow[t]{3}{*}{10} & Udaipur & UPR, BSW \& SRO & 66148 & 64816 & 77762 & 58878 & $17.56 \%$ & $-9.16 \%$ \\
\hline & \multicolumn{2}{|l|}{ Total } & 631002 & 615875 & 743509 & 576508 & $\begin{array}{l}17.83 \\
\%\end{array}$ & $-6.39 \%$ \\
\hline & \multicolumn{2}{|c|}{ Previous Year } & 578057 & 524631 & 631002 & 615875 & $9.16 \%$ & $17.39 \%$ \\
\hline
\end{tabular}

- After restructuring of secondary switching areas (SSAs), many SSAs were combined as detailed above.

- In order to compete with JIO BSNL also launched aggressive plans like $2 \mathrm{~Gb}$ and $3 \mathrm{~Gb}$ per day at a very competitive rates. After this data volume growth of more than $450 \%$ was observed but revenue has fallen which has to be filled for CFA segment i.e. Data Circuits, lease lines and MPLS VPN etc.

\section{Suggestions and Recommendations: -}

- Government to ensure level playing field for all service providers

- Government to provide subsidy to BSNL for providing services in loss making rural area

- Bundling of smart phones with services to be given financial support like NO GST on hand sets and services provided by Government.

- Developing and making smart phones under "Make in India" mission with tax and interest subsidy.

- Making mandatory for builders and colonizer to develop infra for providing FTTH and copper connection in their colonies and apartments.

- Induction of cost effective value added services like E-Library, Online Tutor, E-consultation with doctors, advocates and financial advisors and many more of diverse need $\&$ interest.

- Content in local language.

- Dubbing of videos in local language so that user can learn and understand the content of his need and interest.

- Right of way to install equipment's and remove hurdles of local authorities.

- Fibre/broadband highways sharing like passive infra sharing in mobile may be made mandatory for faster roll out and optimum utilization.

- For wireless broadband spectrum prices to be lowered.

- Initiative to increase digital literacy.

- IP TV services will further increase broadband penetration and combo plan may reduce broadband tariff.

- A nation-wide drive in the form of marketing campaign by the regulator will pave way for the awareness and importance of Data products to facilitate growth in Social, Medical, Education and Government Sectors 
With increased broadband penetration E-governance, transparent system, digital transaction and development in whole economic arena will be reflected provided digital literacy is promoted and public is made aware and services and devices to use services remain within reach of common man.

\section{Conclusion:-}

(i) Growth Details: -With the induction of broadband services on copper pair (ADSL Broadband) and FTTH services new stream of revenue generation emerged for BSNL Rajasthan. The combined ADSL BB and FTTH services the growth details for the period 2009 to 2017 were as follows.

- Capacity of 484224 ports was inducted in the BSNL Rajasthan network in phased manner through many projects for catering demand of present and somewhat future.

- The Combined CAGR (in \%) average connections were $8.08 \%$ for overall total Rajasthan and Jhunjhunu SSA recorded highest CAGR of $19.98 \%$ followed by Sriganganagar $12.11 \%$ followed by Bhilwara $11.25 \%$

- The Combined CAGR (in \%) of ABF (amount billed for) was 12.19\% for overall total Rajasthan and Jhunjhunu SSA recorded maximum $27.31 \%$ followed by Bhilwara $18.19 \%$ and Sriganganagar $15.54 \%$

- The Combined CAGR (in \%) of Revenue realised was $12.39 \%$ for overall total Rajasthan and Jhunjhunu SSA recorded highest CAGR of $26.11 \%$ followed by Bhilwara $16.80 \%$ and Sriganganagar $15.75 \%$

(ii)Benefit of first entrant, monopoly on local loop underground copper cable, PAN India presence, experienced man power, $100 \%$ Government run PSU, transparency in working and tariffs, many proactive and attractive schemes introduction were the factors which led to growth of BB and FTTH services.

(iii)Affordability for connectivity and device, Human Skill and Language, Challenges to roll out services, The Digital divide, lower average bandwidth, Hyper competition market and falling tariff regime, strengthening of sales and distribution network, Matching Coverage with private operators, Legacy of Government department in the attitude of the staff were the challenges for getting desired growth.

(iv)High capital cost bandwidth and linear connectivity, recovery of investment unprofitable and nonviable, nonavailability of copper as last mile connectivity, laying of OF-cable costly affair, very high mean time to repair, bad condition of copper pair, higher tariff of Internet usages, non-availability of last-mile broadband connectivity, nonavailability of electricity, less awareness about services rendered, marketing budget, poor visibility of BSNL, ONT not Wi-Fi enable, ROW(Right of way ) issues, expired battery sets of ONT, non-feasible area were the bottlenecks in growth.

(v)Need of Level playing field for all TSP's, Subsidy to BSNL for rural area, financial support for smart phones , tax and interest subsidy, Content in local language, Right of way hurdle removal, mandatory fibre/broadband highways sharing for faster roll out and optimum utilization, lowering wireless broadband spectrum prices ,Initiative to increase digital literacy, use of IP TV services for more broadband penetration, combo plan to reduce broadband tariff, nation-wide marketing campaign for the awareness and importance of Data products to facilitate growth in Social, Medical, Education and Government Sectors were few suggestions and recommendations.

\section{References:-}

1. Mishra Suresh, Sreekumaran S.K, Chadah Sapna (2015), Consumer Handbook, by Department of Consumer Affairs Government of India, ISBN: 81-86641-57-2(pp1-64).

2. National Telecommunications Policy (2012)-by Department of telecommunications (PP -1-20), extracted from www.dot.gov.in

3. TRAI (2015), Consumer's handbook on Telecommunications- by Telecom Regulatory Authority of India, (pp1-48), extracted from www.trai.gov.in

4. Ibarra C. Venus -\&, Revilla D. Charito (2014) -In their study on “CONSUMERS' AWARENESS ON THEIR EIGHT BASIC RIGHTS: A COMPARATIVE STUDY OF FILIPINOS IN THE PHILIPPINES AND GUAM “-International Journal of Management and Marketing Researchwww.theIBFR.com ISSN: 1933-3153 (print) ISSN: 2157-0205 (online) Vol. 7, No. 2, 2014, pp. 65-78

5. Ishak Suraiya \& Zabil Nur Faridah M (2012)-In their study on "Impact of Consumer Awareness and Knowledge to Consumer Effective Behaviour"- Asian Social Science; Vol. 8, No. 13; 2012 ISSN 1911-2017 E-ISSN 1911-2025 Published by Canadian Centre of Science and Education

6. ITU (2016)-In their study on "Regulatory Issues for Consumer Protection in Digital Financial Services"-

7. Kaur Prabhjo \& Kaur Inderjot(2014-15)-In their study on "Consumer Awareness in Rural Area"- SOPAAN :ISSN-2349-9893 Oct'14-March'15 
8. Rengarajan.P(2012)-In his study" Consumer awareness level of value added services on mobile phone service providers". Study of Vidyasagar College of Arts \&Science, Udumapet. Vol 1 (10). ISSN-2277-1166. (pp 4457).

9. Sharma Dr P. K (2015)-In his study "Broadband Services in India: Problems and Prospects" --Pacific Business Review International Volume: 8, Issue: 5, November 2015, pp 102-11

10. Sinha Naveen Kumar (2013)-In his study on "INDIAN WIRELESS DATA BUSINESS - CHALLENGES AND FUTURE PROSPECTS"-I.J.E.M. S (International Journal of Engineering and Management Science)., VOL.4 (2) 2013:121-124 ISSN 2229-600X, Page 121-124

11. Vel-murugan Mani-vannas Senthil and Vel-murugan Masa Sakthu.2013- In their study "Customer awareness, perceived ease of use towards information technology, Adoption in 3G media phones usage in India". Study of D.B. Jain College, University of Madras, Chennai, India. ISSN:1819-1924(pp1-23).

12. Wadhe P. Amit and Ghodke Shamrao(2013)-In their study "consumer awareness \& perception towards usage of Mobile Banking"- IBMRD's Journal of Management and Research, www.ibmrdjournal.com Print ISSN: 2277-7830, Volume-2, Issue-1, March 2013

13. Websites:-www.trai.gov.in

14. Websites :-www.dot.gov.in

15. Websites:-www.consumeraffairs.nic.in

16. Websites:-www.deity.gov.in/

17. Websites:-www.bsnl.co.in

18. Websites:-www.bbnl.nic.in/content/

19. http://india.gov.in/official-website-ministry-power

20. Websites:-www.coai.com/statistics/mobile-coverage

21. Websites:-www.oecd.org/sti/ict/broadband 